\title{
Tonga: 2008 Article IV Consultation-Staff Report; Staff Supplement; and Public Information Notice on the Executive Board Discussion
}

Under Article IV of the IMF's Articles of Agreement, the IMF holds bilateral discussions with members, usually every year. In the context of the 2008 Article IV consultation with Tonga, the following documents have been released and are included in this package:

- $\quad$ The staff report for the 2008 Article IV consultation, prepared by a staff team of the IMF, following discussions that ended on April 18, 2008, with the officials of Tonga on economic developments and policies. Based on information available at the time of these discussions, the staff report was completed on June 17, 2008. The views expressed in the staff report are those of the staff team and do not necessarily reflect the views of the Executive Board of the IMF.

- $\quad$ A supplement on the joint IMF/World Bank debt sustainability analysis.

- $\quad$ A Public Information Notice (PIN) summarizing the views of the Executive Board as expressed during its July 2, 2008 discussion of the staff report that concluded the Article IV consultation.

The policy of publication of staff reports and other documents allows for the deletion of market-sensitive information.

Copies of this report are available to the public from

International Monetary Fund $\bullet$ Publication Services

$70019^{\text {th }}$ Street, N.W. $\bullet$ Washington, D.C. 20431

Telephone: (202) 623-7430 • Telefax: (202) 623-7201

E-mail: publications@imf.org •Internet: http://www.imf.org

Price: $\$ 18.00$ a copy

International Monetary Fund

Washington, D.C. 



\section{INTERNATIONAL MONETARY FUND}

TONGA

\section{Staff Report for the 2008 Article IV Consultation}

Prepared by the Staff Representatives for the 2008 Article IV Consultation with Tonga Approved by Jeremy V. Carter and Anthony Boote

June 17, 2008

- Discussions: Nuku'alofa, April 9-18, 2008. The team met with Prime Minister Sevele, Minister of Finance Matoto, National Reserve Bank of Tonga Governor Mafi, and other senior government officials, as well as private sector representatives.

- Team: Mses. Liu (Head), Fujita, and Mr. Vitek (all APD). Ms. Cocker (OED) joined the discussions.

- Past surveillance: The 2007 Article IV Consultation was completed on July 11, 2007. Executive Directors' views and comments can be found at http://www.imf.org/external/country/TON/index.htm.

- Focus of discussions: Near-term macroeconomic policies should be geared toward reviving growth while containing inflation and vulnerability. Over the medium term, policies will need to aim at putting the budget on a sound footing, improving debt dynamics, and promoting investment and structural reform to boost private sector-driven growth.

- Outreach: The mission held a press conference on April 18, and also met with business, donor, and diplomatic representatives.

- Exchange rate: Basket peg to the U.S., Australian, and New Zealand dollars and Japanese yen, with monthly adjustment band of \pm 5 percent.

- Exchange system: Accepted the obligations of Article VIII, Sections 2, 3, and 4. The authorities plan to retain the exchange restriction in the form of a tax certification requirement applied to various current international transactions, and agreed to review this requirement in the context of the 2009 Article IV consultation discussions. The Board approved this restriction until July 9, 2008 or the 2008 Article IV consultation, whichever is earlier. At this point, staff does not propose an approval of this restriction.

- Statistics: Data quality, coverage, and timeliness have been hampered by several deficiencies, including capacity constraints, which have complicated effective surveillance. 
Executive Summary...... 3

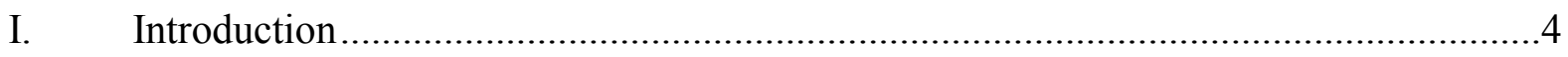

II. Economic and Policy Developments .............................................................

III. Policies to Improve Resilience and Sustain Recovery ...........................................

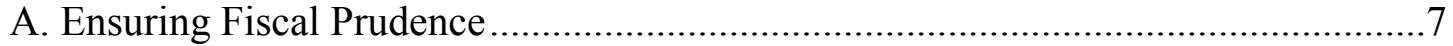

B. Moving Toward Monetary Tightening and Increased Exchange Rate Flexibility ....8

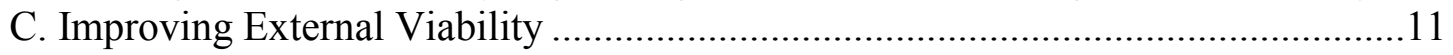

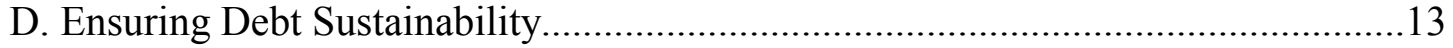

E. Structural Reform and Capacity Building ...................................................... 14

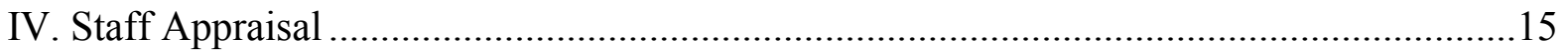

Boxes

1. The Civil Service Wage Settlement ....................................................................

Figures

1. Economic Developments 2002/03-2007/08 .....................................................18

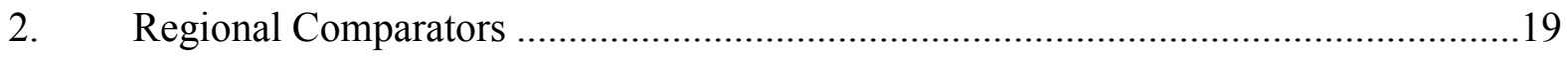

Tables

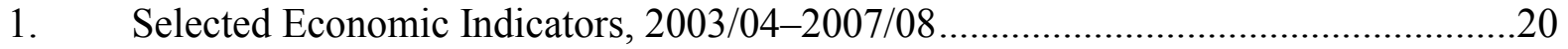

2. Summary of Government Operations, 2003/04-2008/09 .......................................21

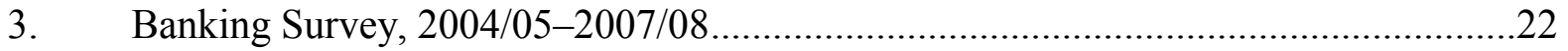

4. Balance of Payments Summary, 2003/04-2008/09 …...........................................23

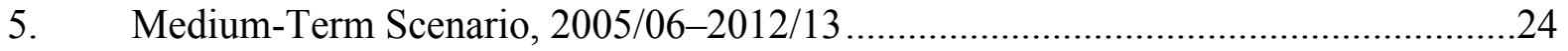

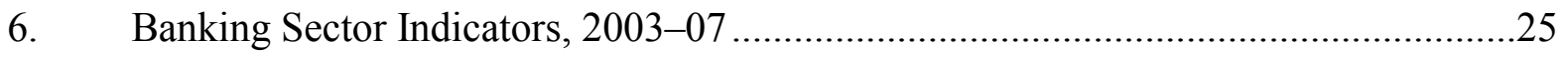




\section{EXECUTIVE SUMMARY}

Background: Tonga's economy has shown resilience in the aftermath of the November 2006 riots, with policies and strong remittances underpinning the recent recovery. Government reconstruction loans and the King's coronation in August 2008 may provide additional growth stimulus. However, the global upswings in fuel and food prices have intensified pressures on inflation and external reserves. Outward migration has been substantial, and strong remittances have become the key mitigating factor to external shocks. Near-term growth prospects are favorable, but risks remain, particularly from further hikes in world food and fuel prices.

Main Issues: Adverse terms-of-trade shocks have complicated economic management in delivering low inflation and stable growth, while safeguarding external stability. As recognized by the authorities, it is important to improve Tonga's resilience to external shocks through rebalancing the policy mix toward a tighter monetary stance, supported by fiscal prudence and increased exchange rate flexibility.

Staff's Views: Rebalancing the policy mix would improve the macroeconomic framework to address concerns of rising inflation and external vulnerability.

- $\quad$ On the fiscal front, a balanced budget in FY07/08 is likely to be achieved, and maintaining this stance in FY08/09 is crucial to sharing the burden of macroeconomic management while generating fiscal savings to buffer increases in debt service over the medium term. Achieving this objective will require sustainable fiscal measures to further improve tax administration and rationalize capital spending in line with donor financing and Tonga's implementation capacity. Moving toward a more orderly public wage policy is also critical to reduce fiscal vulnerability arising from ad hoc and large wage adjustments experienced in the past.

- $\quad$ The joint WB/IMF Debt Sustainability Analysis suggests that with the proposed reconstruction loan, Tonga remains at a high risk of debt distress, mitigated by large remittance inflows. Debt sustainability hinges on a phased utilization of the loan in line with the medium-term fiscal framework to support capital projects that will generate growth and employment opportunities. Tonga should rely as much as possible on donor grants to finance future development.

- $\quad$ Early actions to tighten monetary policy are warranted to anchor inflation expectations in advance of the finalization of the FY08/09 budget. Monetary tightening should be achieved through the use of effective, market-based instruments, including the issuance of central bank notes.

- $\quad$ Rebalancing the policy mix would support increased exchange rate flexibility to safeguard reserves while keeping inflation under control, as well as help correct a likely modest overvaluation of the pa'anga to ensure external stability over the medium term.

Authorities' Views: There was broad agreement on issues and policy requirements. The authorities are aiming at a balanced budget and will take additional measures if needed to ensure the target is met. On the monetary front, the authorities acknowledged that inflation has already exceeded their comfort zone of single digit levels. They are committed to tightening monetary policy, if necessary, to safeguard reserves and contain inflation. They noted that the magnitude of exchange rate depreciation will be carefully considered given its inflationary impact. 


\section{INTRODUCTION}

1. Tonga's economy has shown resilience in the aftermath of the November 2006 riots and is now on a path to recovery. ${ }^{1}$ The key factor underpinning resilience has been private investment. Donor supported government reconstruction loans are expected to add further momentum to the recovery. The King's coronation in August 2008 may also provide additional growth stimulus. Political stability seems to have been restored, and the parliamentary election in late April 2008 did not generate any marked discontent.

2. The global upswings in fuel and food prices, however, have intensified pressures on inflation and external reserves, the latter mitigated to a large extent by strong inflows of remittances. Tonga continues to rely heavily on imports, mostly of food and fuel, while its export base remains narrow, making the trade balance highly vulnerable to major external price shocks. With limited employment opportunities, outward migration has been substantial, and remittances from abroad have risen steadily. Remittances are now the key mitigating factor to external shocks.

3. The economy continues to face structural and policy impediments that undermine growth. Over the past decade, real GDP growth averaged 1.9 percent, underperforming most other Pacific Island countries (PICs). High costs of labor and energy, limited export diversification, and the lack of long-term investment to improve productivity and efficiency are among the main factors that continue to impede high sustainable growth.

4. Against this background, discussions centered on the appropriate policy mix to improve the economy's resilience to external shocks, supported by medium-term structural reforms to improve growth potential. Staff recommendations would facilitate progress toward achieving the authorities' objectives of lowering inflation and maintaining external stability, while supporting economic recovery under a less favorable global environment.

\section{ECONOMic ANd Policy Developments}

\section{Background}

5. Tonga's output growth was severely disrupted in FY06/07 (ending June), following the November 2006 riots. Policies and strong remittances have underpinned the recent recovery (Table 1$)$.

\footnotetext{
${ }^{1}$ Tonga's constitutional monarchy was challenged by a vocal force calling for a move toward more democracy following the death of the previous King Topou IV in September 2006. In November 2006, the government's rejection of a proposal to increase popular representation in parliament sparked riots in the capital city, Nuku'alofa, with estimates of losses in infrastructure and inventories exceeding 10 percent of GDP.
} 
- Real GDP contracted by about 31/4 percent in FY06/07 (following $3 / 4$ percent growth a year earlier), but the private sector quickly relocated their businesses and replenished their lost inventories. Preliminary indicators for the first half of FY07/08 suggest that the economy is on a path to recovery led by the services sector. Nevertheless, the agricultural sector continues to contract, with its dominant

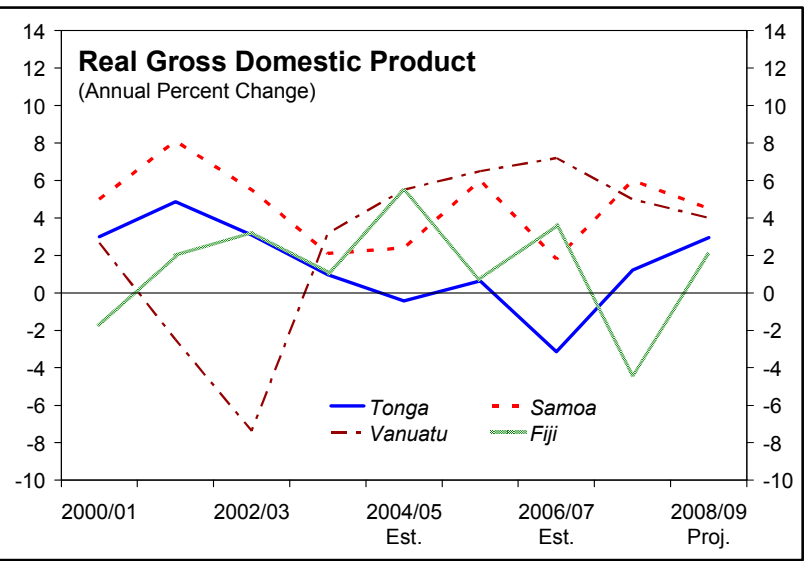
export crop, squash, continuing to suffer from sub-optimal quarantine standards, financing difficulties, and sluggish demand in the niche market overseas.

- Adverse terms-of-trade shocks contributed to inflation pressures. Major increases in external food and fuel prices, combined with a nominal depreciation of the pa'anga against the currencies of major trading partners, have led to a marked increase in CPI inflation, which reached $12^{1} \frac{1}{2}$ percent at end-March 2008 (from 63/4 percent at end-December 2007). Domestic CPI inflation appears to be on a rising trend

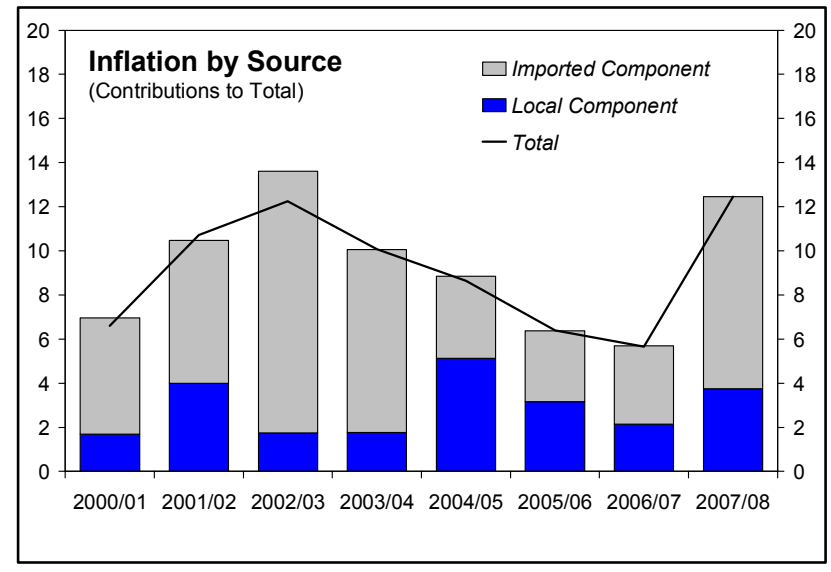
as well, albeit modest, suggesting a recovery in domestic demand, while monetary easing in early 2007 may have also played a role. The impact of the public wage settlement on inflation was somewhat offset by retrenchment of about 20 percent of total civil service workers (Tables 2 and 3).

- Tonga's external position weakened in the last few years, reflecting mainly the impact of rising fuel prices (Table 4). The current account deficit in FY07/08 is projected to remain at about 10 percent of GDP, as further increases in food and fuel prices are expected to be largely offset by increases in remittances. External reserves have declined somewhat since last June to around 3month of imports, and are likely to

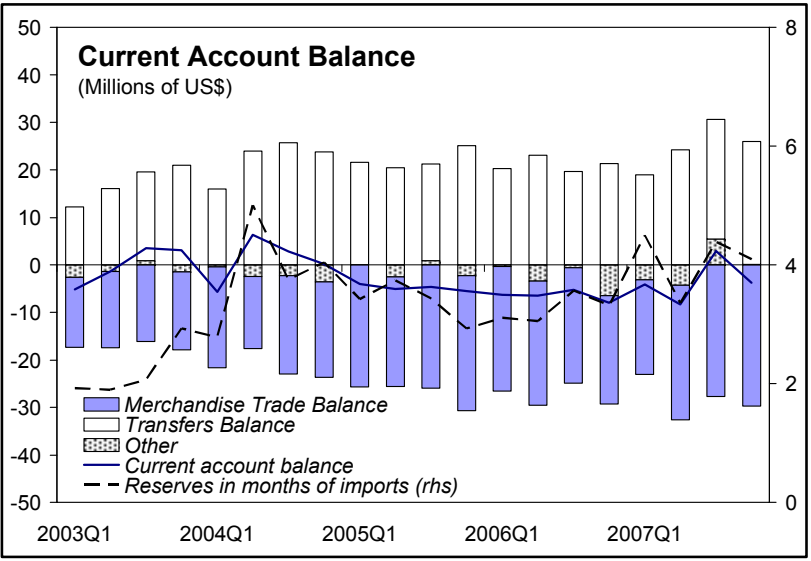
continue this downward trend towards end-FY07/08 reflecting the recent fuel price hikes. 


\section{Outlook and Risks}

\section{Prospects for economic recovery are favorable, but with downside risks, particularly from further hikes in world fuel and food prices in the near term (Table 5).}

- Near term: Real GDP is projected to expand by 11/4 percent in FY07/08, underpinned by a recovery in private domestic demand, while the contribution of external demand to growth remains negative. Inflation is expected to remain high at above 10 percent over the next few months, reflecting the combined effect of the pass-through of higher fuel and food prices and a further modest depreciation of the pa'anga against the currencies of Tonga's major trading partners.

- Medium term: Real GDP growth is expected to reach 23/4 percent in FY08/09 as reconstruction activity gains momentum, and to return to its long-run average of $13 / 4$ percent over the medium term. Inflation is expected to trend downward as world prices of fuel and food are projected to stabilize over the medium term (based on the WEO assumptions).

- Near-term risks: On the upside, the King's coronation in August 2008 is likely to stimulate growth through rising remittances, hotel occupancy, and consumption spending in the run-up to the event. On the downside, high fuel and food prices could entrench high inflation and intensify external vulnerability, weakening domestic confidence and real economic activity. The King's coronation could also possibly lead to spending overrun in the budget.

- Medium-term risks: Tonga has untapped growth potential, especially in tourism, and a strong base to support remittances, which could be channeled to productive investment, including for export diversification. However, competition in tourism could be stiff, especially from Fiji where tourism infrastructure and services are significantly more developed. Continued adverse terms-of-trade shocks and the reemergence of wage pressures are major risks to fiscal and external sustainability. Tonga's constitutional reform toward a democratic system could also potentially spark tensions when the process begins in 2010 .

\section{The Authorities' Views}

7. The authorities broadly concurred with these assessments. However, they expect food inflation in Tonga to be somewhat contained as Tonga remains largely a subsistencesupported economy, and if price differentials become significant, Tongans are highly likely to replace the imported food with locally produced root crops. The rising world fuel prices, however, could have a significant impact on inflation as electricity generation in Tonga is entirely fuel based. Moreover, at an average of about two cars per family, higher oil prices could force substitution away from imported food in order to maintain levels of petrol consumption. 


\section{Policies to Improve Resilience ANd SuStain Recovery}

In response to significant adverse terms-of-trade shocks, rebalancing the policy mix toward a tighter monetary stance, supported by fiscal prudence and increased exchange rate flexibility, would address concerns of rising inflation while safeguarding external stability.

\section{A. Ensuring Fiscal Prudence}

\section{Background}

\section{A balanced budget in FY07/08 is likely to be achieved, but maintaining this} stance in FY08/09 will be challenging in the absence of new measures.

- Significant efforts have been made to achieve a balanced budget in FY07/08. During the first nine months of FY07/08, revenue performance remained buoyant, boosted by a recovery of arrears and a containment of the public wage bill and nonwage spending.

- The authorities have proposed a balanced budget in FY08/09 to limit domestic and nonconcessional external borrowing, but there are downside revenue risks. The budget proposes over 20 percent growth in tax revenue to support higher maintenance and

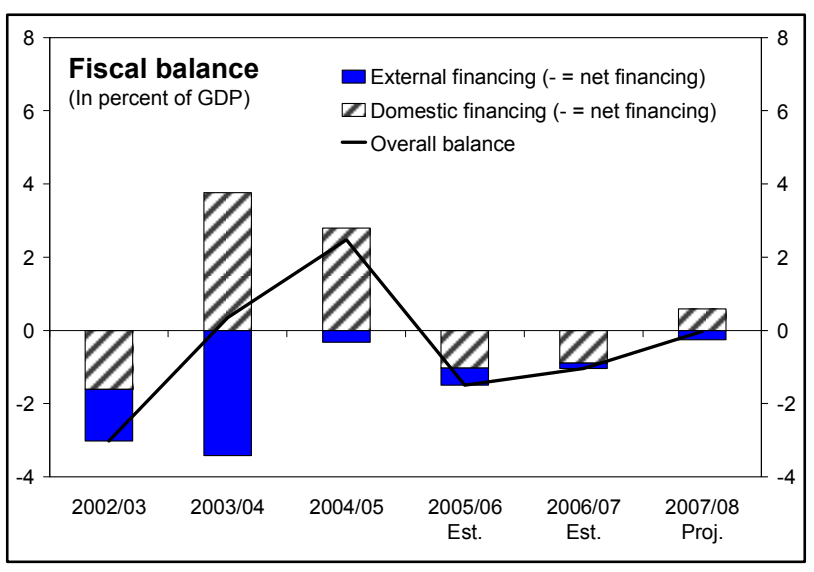
capital spending. At the same time, the budget also focuses on improving business competitiveness through a reduction in the maximum tariff rate to 20 percent (from 45 percent). In addition, it aimed at supporting household disposable income by lifting the individual income tax exemption threshold to TOP7,400 (from TOP2,500), together with a reduction in the corporate tax rate for large taxpayers.

\section{Policy Issues and Staff Views}

\section{Continued fiscal prudence is warranted to share the burden of macroeconomic} management to ensure domestic and external stability in the near term, while generating fiscal savings to buffer increases in debt service over the medium term.

- Achieving a balanced budget in FY08/09 will require sustainable fiscal measures, particularly by further improving tax administration and rationalizing capital spending. It is important to maintain the momentum of tax revenue collection achieved so far, while containing allocations of contingency funds and rationalizing capital spending priorities to a level that is in line with Tonga's implementation capacity and the availability of nondebt generating financing. 
- A more orderly public wage adjustment process is also important to reduce fiscal vulnerability. The wage bill remains large by regional standards. A sustainable wage structure could include annual wage adjustment broadly in line with inflation, supported by limited public hiring and a gradual decompression of the public wage structure to retain high-skilled workers. Moreover, public wage adjustment will need to be formulated within a medium-term fiscal framework to ensure fiscal sustainability (Box 1).

\section{The Authorities' Views}

10. The authorities are committed to a balanced budget, and there are contingency funds to buffer potential shortfalls in tax revenue. They noted that, if necessary, additional expenditure measures will be taken, mostly through prioritization of capital spending, to ensure limited recourse to domestic financing. They have already revived a high level Expenditure Review Committee to conduct quarterly budget reviews with the aim to minimize possible fiscal slippages.

\section{B. Moving Toward Monetary Tightening and Improved Exchange Rate Flexibility}

\section{Background}

11. Monetary policy was eased in several steps in early 2007 to support economic recovery. At the time, inflation was less of a concern. The impact of monetary easing has only started to materialize recently.

- Private sector credit growth picked up gradually. It reached $16 \frac{1}{2}$ percent $(\mathrm{y} / \mathrm{y})$ at end-February 2008, from $6 \frac{1}{2}$ percent at end-March 2007. Banks' business loans, however, grew at a faster pace (to almost 30 percent by endDecember 2007), while growth in housing loans has been relatively slow.

- Excess liquidity climbed up to over

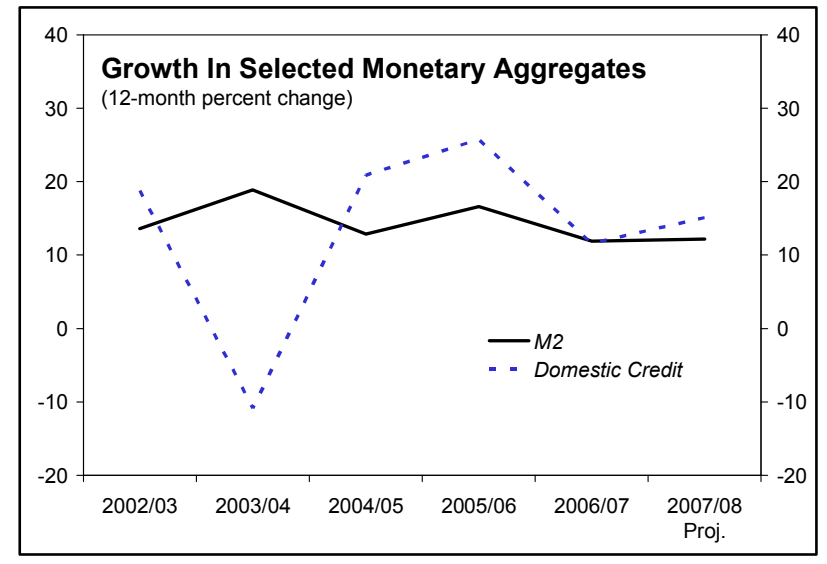
30 percent of reserve money in early 2008, but it has declined to around 10 percent in recent months. This draw down was largely used to finance oil imports, with a corresponding decline in NFA of the NRBT. 


\section{Box 1. Tonga: The Civil Service Wage Settlement}

\section{Substantial wage settlements over the past few years have imposed significant challenges to fiscal management.}

Following a civil service strike that lasted six weeks, the government and the Public Service Association agreed in September 2005 on a large civil service wage increase of 60-80 percent, with the wage increase for $\mathrm{FY} 05 / 06$ to be paid in two phases during FY05/06 and FY06/07. To partly offset these large wage increases, the government carried out a major voluntary redundancy program in April-June 2006, reducing personnel by 18 percent.

\section{These developments had significant}

fiscal implications. The total cost of the wage settlement, including one-off payments such as severance package, accounts for about 9 percent of GDP in FY05/06, and 33/4 percent in FY06/07. Despite the substantial civil service retrenchment in end-FY05/06, the wage bill is still projected to increase to $13 \frac{3}{4}$ percent of GDP in FY07/08 from its pre-settlement level of $11 \frac{3 / 4}{4}$ percent in FY04/05.

\section{An orderly wage-setting mechanism is} needed to enhance fiscal management. Periodic and sizable nominal wage increases were often the result of years of real wage compression which left public wages substantially below levels in the private sector. With assistance from the Asian Development Bank, the government introduced performance-based contracts for public workers in 2003, granting high salary increases to senior workers to help recruit and retain qualified staff. However, increased salary disparities caused widespread dissatisfaction among civil servants at lower grades, which triggered the civil service strike in 2005. Introducing a sound public wage policy may require the support of labor unions, as well as the acceptance of the civil servants to the needed reform.



\section{Policy Issues and Staff Views}

12. Monetary easing in early 2007 was appropriate to revive the economy at a time of low inflation, but a shift towards monetary tightening is warranted now with the economy recovering and inflation rising.

- Early monetary actions are needed to anchor inflationary expectations in advance of the finalization of the FY08/09 budget. This is crucial to minimize wage pressures and to prevent high inflation from becoming entrenched, as well as to help contain liquidity pressure on the balance of payments.

- Monetary tightening should be achieved through the use of effective, market-based instruments, including the issuance of NRBT notes and increases in reserve requirements. The reliance on administrative controls, such as credit ceilings, should be limited.

- The NRBT could also step up prudential measures to help monitor the fast growth in business loans. A continuation of this trend could pose risks to financial stability going forward, especially in an environment of low growth that could undermine business and households' debt servicing capacity. The enactment of amendments to the NRBT Act, approved by parliament in August 2007, will help further enhance the NRBT's capital base, strengthen its accountability in bank operations, and clarify its profit transfer rules.

\section{The Authorities' Views}

13. The authorities are committed to tighten monetary policy if necessary in order to safeguard reserves and contain inflation, supported by a balanced budget.

- Monetary actions are guided by two key considerations: maintaining reserves at a minimum of three months of imports and keeping inflation under control. The authorities acknowledged that inflation is already running at above their comfort zone of single digit levels, and they are closely monitoring external developments, particularly oil payments and remittances, as both items have significant but offsetting implications for reserves.

- The NRBT concurred that relying on market-based instruments is desirable. They noted, however, that the issuance of NRBT notes will only be efficient if there is excess liquidity in the system. Achieving monetary tightening beyond that stage may require the use of other instruments, including statutory reserve requirements and credit ceilings, to contain credit growth. A continued reliance on NRBT notes at that stage may result in increased costs for the NRBT, undermining its own financial soundness. 


\section{Improving External Viability}

\section{Background}

14. Staff analysis suggests that Tonga's REER appears to be broadly in line with economic fundamentals, although quantitative estimates point toward a likely overvaluation that could be corrected within the adjustment band under the current exchange rate regime. The results are subject to considerable uncertainty due to significant data deficiencies.

- Recent balance of payments dynamics appear sustainable, although trade performance warrants close monitoring in light of a sustained rise in international fuel and food prices. In the absence of further major external shocks, the current account deficit as a share of GDP is expected to narrow significantly over the medium term as fuel and food prices stabilize. Under this scenario, reserves should remain at around three months of imports. The recent progress with banks to reduce the transaction costs for remittances should support continued strong inflows, which will in turn help reduce external vulnerability. However, the external vulnerability could be aggravated by further increases in food and fuel prices.

- Quantitative assessments of Tonga's REER indicate a likely overvaluation of 510 percent, which could be corrected within the monthly adjustment band under the current exchange rate regime. ${ }^{2}$

- $\quad$ The NRBT seems to have made little use of exchange rate flexibility since 2003, reflecting concerns about the inflationary impact of further currency depreciation. The pa'anga depreciated by $2 \frac{1 / 4}{4}$ percent in nominal effective terms in 2007 against a weighted basket of major currencies, while it appreciated by 5 percent vis-à-vis the U.S. dollar. In real effective terms, the pa'anga appreciated by $13 / 4$ percent, reflecting mainly inflation rate differentials with Tonga's trading partners.

\section{Policy Issues and Staff Views}

15. Following a depreciation of about 9 percent during 1997-2003, the REER appreciated by 13 percent over 2003-07, reflecting mainly externally driven higher inflation in Tonga relative to its trading partners.

\footnotetext{
${ }^{2}$ Under a modified version of the Macroeconomic Balance (MB) approach, the REER overvaluation is estimated at $3 \frac{1}{2}$ percent in 2006/07, whereas the equilibrium real exchange rate (ERER) approach suggests an overvaluation of about 10 percent. The external sustainability (ES) approach suggests that the REER would need to depreciate by $8 \frac{1}{2}$ percent to stabilize the NFA of the banking system at its end-2006/07 level (17 percent of GDP); economy-wide international investment position data are not available.
} 

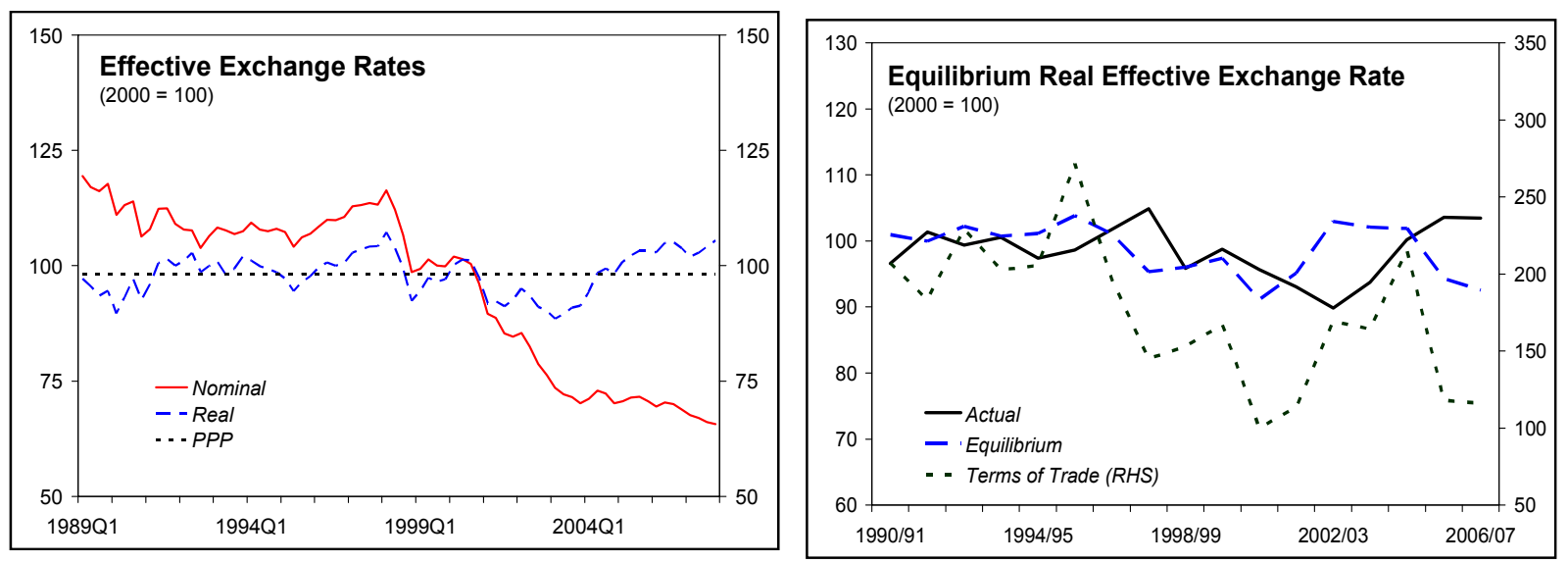

16. External price competitiveness does not seem to be an immediate concern.

Tonga's exports remain small (less than one-tenth of imports), and its major export product, squash, is limited to a niche market in Japan where competitiveness is dominated by factors such as local production patterns, quarantine standards, and other factors such as bilateral preferential tariff treatment. Staff's preliminary assessment indicates that the current weights in the currency basket remain broadly in line with Tonga's currency composition of trade, provided that export revenues are augmented with remittance receipts, which may be viewed as derived from service exports of human capital.

\section{Rebalancing the policy mix would support increased exchange rate flexibility to} safeguard reserves while keeping inflation expectations under control. This flexibility in the near term would imply the need for a modest depreciation of the pa'anga in view of the current level of reserves and strong import demand. This should help speed up balance of payments adjustment and a reduction of pressures on reserves by lowering imports, which would help create a virtuous cycle of policies that will reinforce each other to achieve the authorities' policy objectives. Increased exchange rate flexibility within the monthly adjustment band would help correct a likely modest overvaluation of the pa'anga and ensure external stability.

\section{The Authorities' Views}

18. The authorities agreed that recent balance of payments dynamics do not indicate large exchange rate misalignment. While the current account deficit widened during the last few years, this was mainly driven by negative terms-of-trade shocks, and remittance inflows have continued to play a stabilizing role by supporting nearly 80 percent of imports. The authorities expected that, in the event of a slowdown in remittances, imports would decline accordingly. The authorities also emphasized that the current exchange rate regime could provide sufficient flexibility to adjust a possible overvaluation, if needed.

19. External price competitiveness was not a concern of major exporters. Despite the fact that exports of squash have weakened in recent years, exchange rate competitiveness has 
not been seen as a primary contributing factor, in part because squash production relies highly on imported inputs, including fertilizer, while demanding quarantine standards, financing difficulties, and supply side volatility overseas are more of a concern.

20. The authorities noted that the magnitude of exchange rate depreciation will be carefully considered given its inflationary impact. They nevertheless agreed that a prudent fiscal stance and further monetary tightening should allow the NRBT to exercise increased exchange rate flexibility to strengthen the policy framework under less favorable global conditions.

\section{Ensuring Debt Sustainability}

\section{Background}

21. The last Article IV consultation raised concerns about debt sustainability, particularly relating to the size and timing of the China reconstruction loan. Agreement with China's EXIM Bank was signed in November 2007 for a RMB 440 million reconstruction loan, currently valued at about US\$63 million (23 percent of GDP), at 2 percent and 20-year maturity, with a grace period of five years, The initial plan was to disburse the overall amount over a two-year period during 2008/09-2009/10 for the reconstruction of Nuku'alofa. The actual disbursements, however, have been postponed as the private sector has taken a significant lead in the reconstruction efforts. The government is currently reassessing the funding requirement for future reconstruction, and is working on a better-defined framework for the use of this loan.

\section{Policy Issues and Staff Views}

22. Reconstruction will need to be implemented in line with the medium-term fiscal framework to ensure debt sustainability. The Low Income Country Debt Sustainability Assessment (LIC DSA, accompanying document) suggests that Tonga's public and publicly guaranteed external (PPG) debt is manageable in view of the positive debt dynamics over the projection period. For illustrative purposes, the DSA assumes a utilization of US\$10 million of the reconstruction loan per year over FY08/09-FY12/13, with GDP growth rate at historical average and fiscal consolidation. Reflecting Tonga's low exports, however, NPV of external debt and debt service-to-exports ratios are projected to exceed or be close to their respective indicative thresholds of 100 percent and 15 percent, indicating a high risk of debt distress. This risk is significantly mitigated by large remittance inflows. Indeed, remittances have grown over time to reach seven times the value of exports in 2007, are the main sources of foreign exchange earnings, and contribute significantly to revenue and national income.

\section{Limiting the use of nonconcessional financing to support future development}

program is crucial. As the DSA illustrative scenario indicates that, if the reconstruction loan mentioned above is disbursed in large sums over the next two years as initially planned, debt service could jump to over 1 percent of GDP and 3 percent of projected reserves starting in FY13/14 (after a five-year grace period), intensifying risks of external debt distress. 
24. A sound public debt management policy is needed to guide Tonga's future development financing and ensure debt sustainability over the medium term. Given the current public debt dynamics, it is desirable for Tonga to rely as much as possible on donors' grants to finance future development, supplemented by some use of long-term concessional financing. Reliance on nonconcessional external borrowing is highly discouraged.

Development projects will need to be prioritized to be in line with the availability of donor grants and concessional resources, as well as the country's implementation capacity. The private sector should be given a broader role in project implementation to improve efficiency. Fiscal prudence, export diversification, and improved tourism, as well as policies to enhance growth prospects are also critical underpinnings to debt sustainability over the medium term.

\section{The Authorities' Views}

25. The authorities broadly agreed with the general assessment of the DSA, indicating that the overall size and business needs of the reconstruction loan are currently being reviewed. This may lead to a significantly smaller disbursement over a longer horizon than initially planned, along with a well-defined reconstruction program to be financed by such credit. They also noted that donors are planning to step up grant financing for Tonga over the next 2-3 years, but the capacity to fully utilize donor grants will need to be significantly improved. Moreover, a strengthened policy framework and strong remittances should help improve Tonga's capacity in servicing its debt.

\section{E. Structural Reform and Capacity Building}

\section{Background}

\section{Corporatization and privatization of public enterprises has advanced, but} pressure on the government to take over a private power company, Shoreline, currently owned by the King, has increased. ${ }^{3}$ The value of Shoreline was estimated by Deloitte and Touche, an international accounting firm, at US\$21 million in March 2007. Combined with an additional US\$5 million administrative fee, the total value of this transaction could cost the government nearly 10 percent of GDP or 59 percent of reserves. The government is considering using the foreign exchange proceeds from the sale of Westpac Bank of Tonga to help finance this transaction, which could take place in the second half of FY07/08.

\section{Tonga's governance indicators (World Bank, 2006) are perceived as weaker} than those of its regional peers. In particular, administrative impediments to business, including restrictions on business licensing, land issues, and immigration visas, continue to deter investors. However, these indicators may be outdated in view of recent developments in this area. In particular, the Cabinet passed the Procurement Bill in late 2006, and final

\footnotetext{
${ }^{3}$ There is a strong call from general public for the King to divest all his holdings in private companies prior to his coronation in August 2008 to minimize the risk of conflict of interest.
} 
preparations are underway to outsource certain government operations starting in FY08/09. In addition, training courses have been provided on corporate governance and compliance, and task forces have been created to review land, immigration visa, and business licensing issues. The Independent Anti-Corruption Commission has also been granted legal enforcement power to help enforce public governance.

\section{Policy Issues and Staff Views}

28. Structural reform in Tonga should aim at raising efficiency, reducing quasifiscal risks, and improving governance. In this context, the proposal by the government to retake the Shoreline is of concern, including to the donor community.

- In particular, the estimated value of the company seems too large to be absorbed by the fiscal accounts. The use of the foreign exchange proceeds from the sale of Westpac Bank of Tonga for this transaction would undermine the objective of the NRBT to support reserves under increased external pressure.

- The government should make every effort to seek potential investors who may be interested in acquiring Shoreline in the near future. Options to delay payments associated with the underlying financial transaction until Shoreline is sold to private investors should be considered as the best approach.

29. Sound measures to address administrative impediments to investment and increased transparency are two key pillars to improve public governance in Tonga. In this context, implementation of the new Procurement Bill is a step in the right direction. Outcomes of the task forces on governance should also be transformed to concrete, monitorable measures. Moreover, improved public discussion of policies and timely dissemination of information could help correct perceptions.

\section{The Authorities' Views}

30. Efforts will be made to ensure that the repurchase of Shoreline by the government will be transparent, while options are being considered to minimize the fiscal burden of this transaction. While noting the political sensitivity of this issue, the authorities agreed that the search for potential investors should be given priority.

31. There is a need to update the Governance Indicators for Tonga in view of the latest developments. The government is ready to work closely with the donor community to monitor the implementation of the Procurement Bill and further improve transparency.

\section{StAFF APPRAisal}

32. Tonga's economy is recovering from the aftermath of the November 2006 riots. However, adverse terms-of-trade shocks have contributed to inflation and balance of 
payments pressures, and complicated economic management aiming at delivering low inflation and stable growth while safeguarding external stability.

33. As recognized by the authorities, it would be desirable to improve the economy's resilience to external shocks through rebalancing the policy mix. This would require a policy shift toward a tighter monetary stance and a sound fiscal framework to contain inflation, while facilitating greater exchange rate flexibility at a time of significant external pressure.

34. The authorities' commitment to a tighter monetary policy stance is welcome, but early actions are warranted to anchor inflationary expectations, particularly in advance of the finalization of the FY08/09 budget. Monetary tightening should be conducted through the use of effective, market-based instruments, and reliance on credit ceilings should be limited. High credit growth to the business sector may also need to be closely monitored to ensure financial stability. The extent of monetary tightening may need to be reviewed on a timely basis to avoid inflation becoming entrenched.

35. A balanced budget for FY08/09 is appropriate to share the burden of macroeconomic management. Meeting this target requires sustained efforts to limit new public hiring, contain nonwage spending, and improve tax administration. This is crucial to address downside risks arising from new tax measures introduced in the past two years. Further improvement in expenditure management is also essential, including a prioritization of capital projects in line with the availability of donor grants and nonconcessional financing, and Tonga's implementation capacity. The authorities' decision to utilize the Expenditure Review Committee to conduct quarterly budget reviews is timely to help minimize risks of fiscal slippage. Over the medium term, the fiscal framework should aim at small budget surpluses to buffer future increases in debt service payments, underpinned by tax administration reform and a more orderly public wage policy.

36. The exchange rate appears to be broadly in line with economic fundamentals, although quantitative estimates point toward a likely modest overvaluation which could be corrected under the current exchange rate regime. Given the current level of reserves and rising import demand, a modest depreciation of the pa'anga may be required in the near term to speed up a real adjustment in the balance of payments, thereby containing pressures on reserves. An improved policy mix would provide scope for a modest depreciation while keeping inflation expectations under control.

37. The authorities plan to retain the exchange restriction in the form of a tax certification requirement applied to various current international transactions. The Board approved this restriction until July 9, 2008 or the 2008 Article IV consultation, whichever is earlier. In the absence of the firm timetable for the removal of this restriction, staff does not propose further approval of this restriction.

38. Tonga's medium-term debt sustainability hinges on the strength of fiscal consolidation and prospects for securing nondebt-creating flows. Tonga's public debt dynamics reveal that donor grants and long-term concessional loans are the preferred form of 
financing. Recourse to nonconcessional borrowing should be avoided. The reconstruction loan of US\$63 million puts Tonga over the external debt distress thresholds over the medium term, suggesting a high risk of distress. In this context, the authorities' decision to review the size of this loan is timely, and the amount of annual disbursement should be kept to levels consistent with Tonga's medium-term fiscal framework and implementation capacity. Remittances play an important role in significantly mitigating external debt and debt service risks. Nevertheless, a sound public debt management policy, together with export diversification and increased tourism, will further enhance Tonga's debt sustainability.

\section{The government's plan to temporarily renationalize Shoreline should be} carefully reviewed and articulated to the public. Every effort should be made to seek potential investors who may be interested in acquiring the company in the near future. In the meantime, options to delay payments associated with the underlying financial transaction by the government until Shoreline is sold to private investors should be considered.

40. The authorities have made progress in the area of governance, including through the approval by the Cabinet of a Procurement Bill to be implemented in FY08/09. Further efforts are needed to address land, immigration visa, and business licensing issues, which have deterred investment and given rise to public perceptions of weak governance. Moreover, public discussion of policies and timely dissemination of information could help improve transparency and help communicate the authorities' policy intentions.

\section{Improving statistical capacity remains a priority, and further technical}

assistance in this area is needed. The authorities have identified the national accounts and price statistics as priorities in need of technical assistance, and they are encouraged to work closely with PFTAC and AsDB to review the existing TA programs to help address these issues.

42. It is recommended that the next Article IV consultation with Tonga takes place on a standard 12-month cycle. 
Figure 1. Tonga: Economic Developments, 2002/03-2007/08
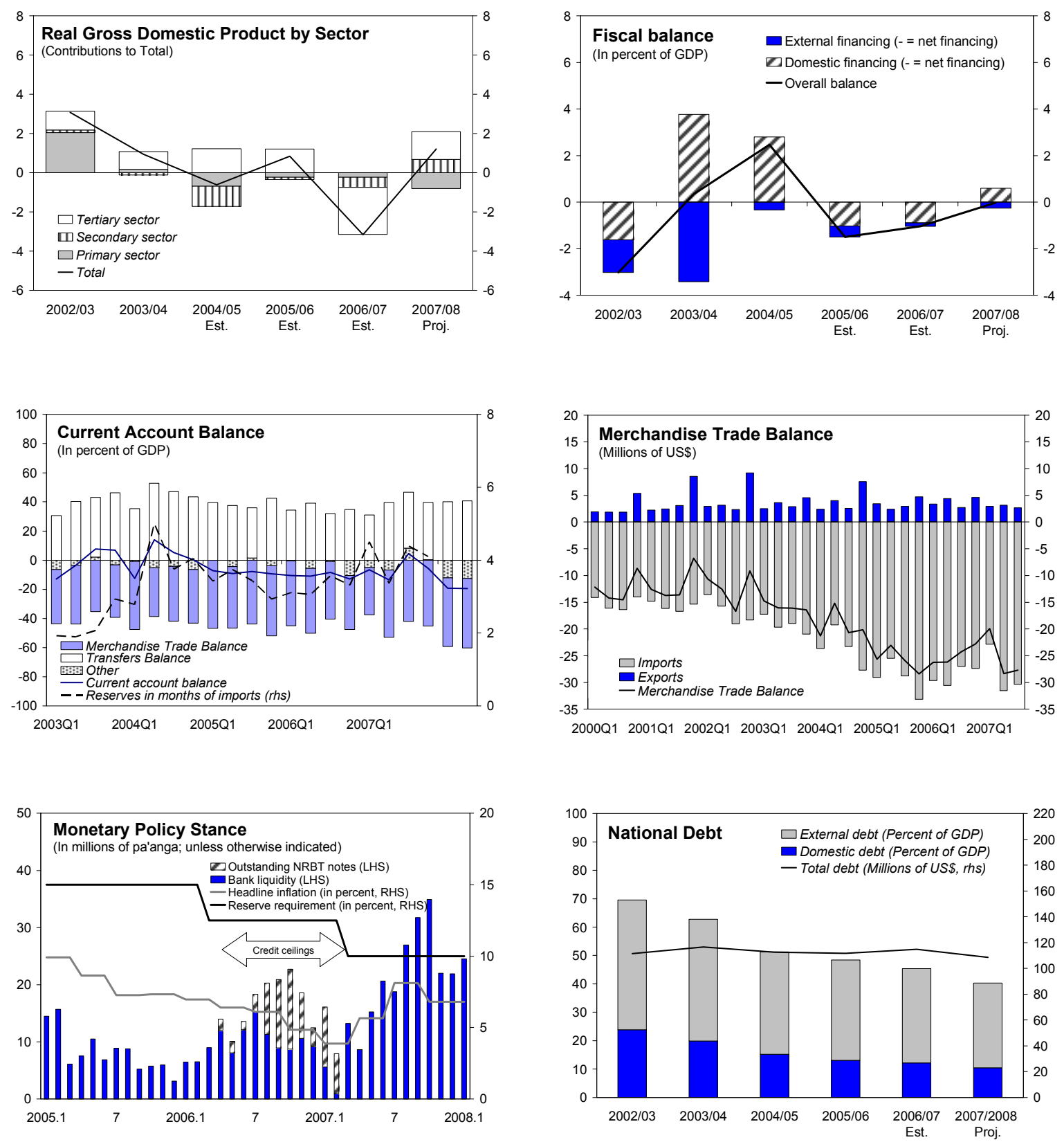

Source: Data provided by Tongan authorities; and Fund staff estimates. 
Figure 2. Tonga: Regional Comparators, (Averages, 2002-2008 1/)
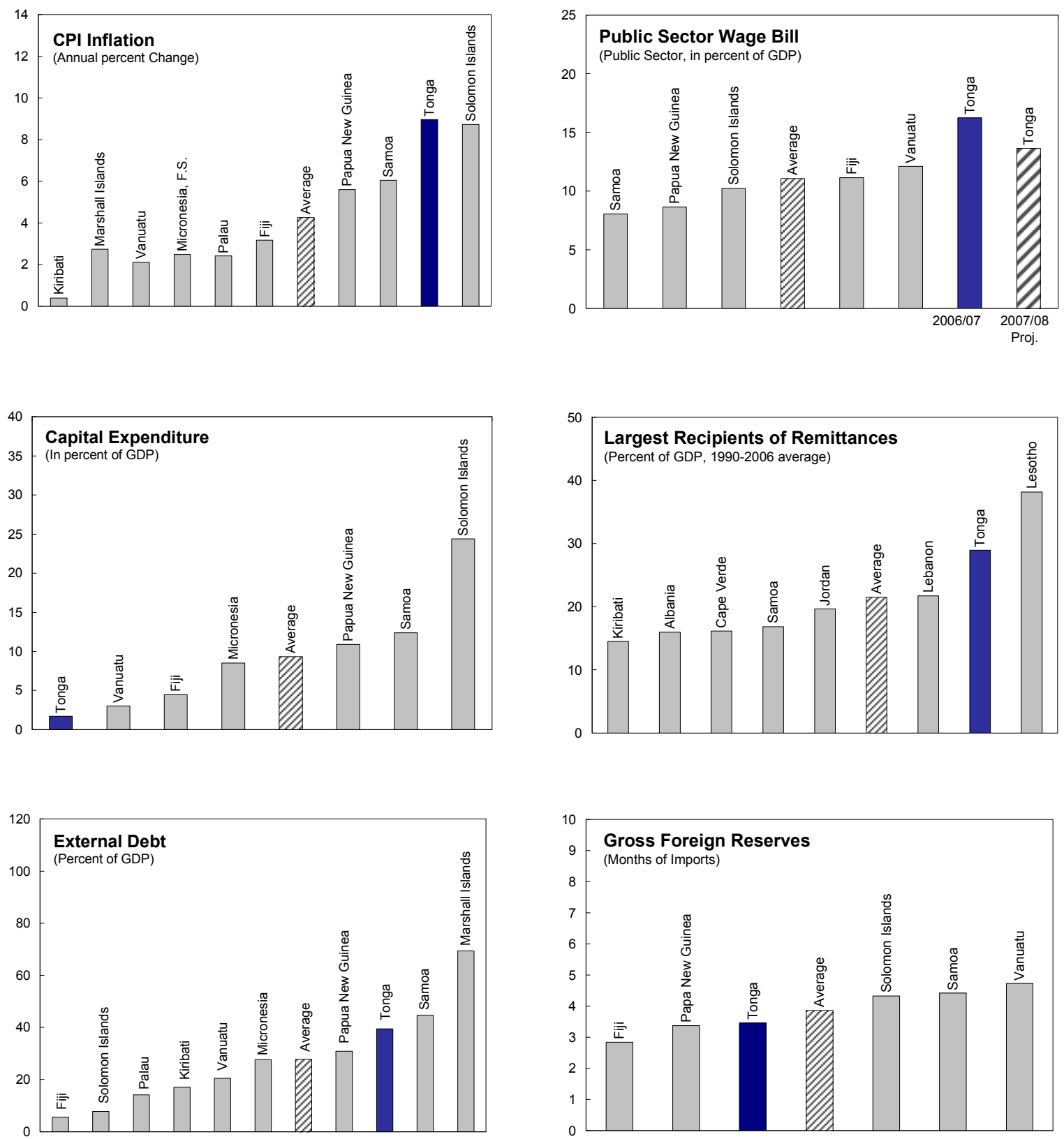

Source: Data provided by Tongan authorities; WEO and Fund staff estimates.

1/ Projection data for 2008 and estimates for 2007. 
Table 1. Tonga: Selected Economic Indicators, 2003/04-2008/09 1/

Nominal GDP (2006/07): US\$ 246.0 million

Population (2007): 102,360

GDP per capita (2006/07): US\$2,433

Quota: SDR 6.9 million

\begin{tabular}{|c|c|c|c|c|c|c|}
\hline & \multirow[t]{2}{*}{$2003 / 04$} & \multirow[t]{2}{*}{$2004 / 05$} & \multirow[t]{2}{*}{$2005 / 06$} & \multirow{2}{*}{$\frac{2006 / 07}{\text { Prel. }}$} & $2007 / 08$ & 2008/09 \\
\hline & & & & & \multicolumn{2}{|c|}{ Proj. } \\
\hline & \multicolumn{6}{|c|}{ (Annual percent change) } \\
\hline \multicolumn{7}{|l|}{ Output and prices } \\
\hline Real GDP & 1.0 & -0.4 & 0.6 & -3.2 & 1.2 & 2.6 \\
\hline \multirow[t]{2}{*}{ Consumer prices (end of period) } & 11.7 & 9.7 & 7.0 & 5.1 & 14.5 & 12.3 \\
\hline & \multicolumn{6}{|c|}{ (In percent of GDP) } \\
\hline \multicolumn{7}{|l|}{ Central government finance } \\
\hline Total revenue and grants & 29.9 & 28.7 & 33.4 & 33.2 & 31.4 & 31.8 \\
\hline Total revenue & 28.5 & 27.4 & 31.3 & 29.8 & 29.4 & 28.6 \\
\hline Grants & 1.4 & 1.3 & 2.1 & 3.4 & 2.0 & 3.2 \\
\hline Total expenditure and net lending & 29.5 & 26.3 & 34.9 & 34.3 & 31.4 & 32.1 \\
\hline Of which: Current expenditure & 27.3 & 25.4 & 35.0 & 32.5 & 30.1 & 30.1 \\
\hline Capital expenditure & 1.0 & 1.0 & 3.2 & 1.1 & 1.3 & 1.8 \\
\hline Overall balance & 0.3 & 2.5 & -1.5 & -1.0 & 0.0 & -0.3 \\
\hline External financing (net) & 3.4 & 0.3 & 0.5 & 0.2 & 0.3 & -0.2 \\
\hline Domestic financing (net) & -3.8 & -2.8 & 1.0 & 0.9 & -0.6 & 0.0 \\
\hline \multirow[t]{2}{*}{ Privatization receipts } & 0.0 & 0.0 & 0.0 & 0.0 & 0.4 & 0.5 \\
\hline & \multicolumn{6}{|c|}{ (Annual percent change) } \\
\hline Money and credit & & & & & & \\
\hline Total liquidity $2 /$ & 16.7 & 13.3 & 13.3 & 13.3 & 13.7 & $\ldots$ \\
\hline Of which: Broad money (M2) & 18.9 & 12.8 & 16.6 & 11.9 & 14.7 & $\ldots$ \\
\hline Domestic credit & -10.9 & 20.9 & 25.8 & 11.6 & 15.1 & $\ldots$ \\
\hline Of which: Private sector credit & -4.3 & 29.4 & 22.6 & 9.5 & 15.5 & $\cdots$ \\
\hline \multicolumn{7}{|l|}{ Interest rates (end of period) } \\
\hline Average deposit rate $3 /$ & 4.6 & 5.1 & 5.2 & 5.6 & 5.7 & $\ldots$ \\
\hline \multirow[t]{2}{*}{ Base lending rate $3 /$} & 9.0 & 9.5 & 9.0 & 9.4 & 9.5 & $\ldots$ \\
\hline & \multicolumn{6}{|c|}{ (In millions of U.S. dollars) } \\
\hline \multicolumn{7}{|l|}{ Balance of payments } \\
\hline Exports, f.o.b. & 13.8 & 16.0 & 15.4 & 13.3 & 14.8 & 15.5 \\
\hline Imports, f.o.b. & -82.6 & -105.4 & -122.2 & -108.6 & -135.0 & -154.3 \\
\hline Services (net) & -2.8 & -10.0 & -7.8 & -17.9 & -14.4 & -13.6 \\
\hline Investment income (net) & -0.4 & 1.6 & 2.8 & 3.5 & 3.7 & 3.6 \\
\hline Services and investment income (net) & -3.2 & -8.4 & -5.0 & -14.4 & -10.7 & -10.0 \\
\hline Current transfers (net) & 79.7 & 91.9 & 88.9 & 84.2 & 104.1 & 126.0 \\
\hline Of which: Private transfer receipts & 90.1 & 107.4 & 102.0 & 93.3 & 116.5 & 138.8 \\
\hline Current account balance & 7.7 & -5.8 & -22.8 & -25.5 & -26.8 & -22.8 \\
\hline (In percent of GDP) & 4.2 & -2.6 & -9.7 & -10.4 & -10.4 & -8.8 \\
\hline Overall balance & 25.9 & -4.0 & 0.6 & 4.2 & -3.7 & 2.6 \\
\hline \multicolumn{7}{|l|}{ Gross official foreign reserves } \\
\hline In millions of U.S. dollars & 44.8 & 42.5 & 40.4 & 47.1 & 43.4 & 46.0 \\
\hline In months of goods and services imports & 4.8 & 3.7 & 3.1 & 3.9 & 3.0 & 2.8 \\
\hline \multicolumn{7}{|l|}{ External debt } \\
\hline External debt (in percent of GDP) & 42.9 & 36.1 & 35.4 & 33.2 & 29.8 & 31.4 \\
\hline Debt service ratio $4 /$ & 8.2 & 8.0 & 7.5 & 9.8 & 11.0 & 10.5 \\
\hline \multicolumn{7}{|l|}{ Exchange rates } \\
\hline Pa'anga per U.S. dollar (period average) 5/ & 2.05 & 1.94 & 2.01 & 2.00 & 1.94 & $\ldots$ \\
\hline Pa'anga per U.S. dollar (end of period) $5 /$ & 2.00 & 1.93 & 2.06 & 1.95 & 1.91 & $\ldots$ \\
\hline Nominal effective exchange rate $(1990=100) 5 /$ & 71.44 & 71.11 & 70.50 & 68.37 & 65.86 & $\ldots$ \\
\hline Real effective exchange rate $(1990=100) 5 /$ & 93.76 & 100.18 & 103.58 & 103.43 & 103.93 & $\ldots$ \\
\hline
\end{tabular}

Sources: Data provided by the Tongan authorities; and Fund staff estimates and projections.

$1 /$ Fiscal year beginning July.

2/ From the Banking Survey, which includes the Tonga Development Bank.

3/ Through 3Q 2007.

$4 /$ In percent of exports of goods and services.

5/ Through January 2008. 
Table 2. Tonga: Summary of Government Operations, 2003/04-2008/09

\begin{tabular}{|c|c|c|c|c|c|c|}
\hline & \multirow[t]{2}{*}{$2003 / 04$} & \multirow[t]{2}{*}{$2004 / 05$} & $2005 / 06$ & $2006 / 07$ & $2007 / 08$ & $2008 / 09$ \\
\hline & & & & Prel. & \multicolumn{2}{|c|}{ Proj. } \\
\hline & \multicolumn{6}{|c|}{ (In millions of pa'anga) } \\
\hline Total revenue and grants & 111.0 & 122.1 & 158.3 & 163.6 & 174.0 & 191.9 \\
\hline Total revenue & 105.9 & 116.6 & 148.4 & 146.7 & 162.8 & 172.7 \\
\hline Current revenue & 105.9 & 116.6 & 148.4 & 146.7 & 162.8 & 172.7 \\
\hline Tax revenue & 86.1 & 98.4 & 125.9 & 126.4 & 144.9 & 152.2 \\
\hline Nontax revenue $1 /$ & 19.7 & 18.2 & 22.5 & 20.3 & 17.9 & 20.5 \\
\hline Capital revenue & 0.0 & 0.0 & 0.0 & 0.0 & 0.0 & 0.0 \\
\hline Grants (in cash) 2/ & 5.2 & 5.5 & 9.9 & 16.9 & 11.2 & 19.2 \\
\hline Total expenditure and net lending & 109.8 & 111.6 & 165.4 & 168.8 & 174.2 & 193.9 \\
\hline Total expenditure & 110.7 & 112.6 & 166.7 & 169.4 & 174.2 & 192.6 \\
\hline Current expenditure & 101.7 & 107.9 & 165.9 & 160.3 & 166.9 & 181.8 \\
\hline Wages and salaries $3 /$ & 45.7 & 49.7 & 90.5 & 80.0 & 76.7 & 81.5 \\
\hline Of which: Redundancy Package & 0.0 & 0.0 & 24.3 & 0.0 & 0.0 & 0.0 \\
\hline Retirement funds employer contribution & 1.5 & 2.6 & 3.8 & 3.8 & 4.4 & 4.7 \\
\hline Interest expense & 3.2 & 3.8 & 3.2 & 3.2 & 4.2 & 4.5 \\
\hline Other current expenditures & 51.3 & 51.8 & 68.3 & 73.4 & 81.7 & 91.0 \\
\hline Capital expenditure & 3.9 & 4.3 & 15.3 & 5.6 & 7.2 & 10.9 \\
\hline Expenditure discrepancy & 5.1 & 0.5 & -14.6 & 3.4 & 0.0 & 0.0 \\
\hline Total lending minus repayments & -0.9 & -1.1 & -1.2 & -0.6 & 0.0 & 1.3 \\
\hline Current balance & 4.2 & 8.7 & -17.5 & -13.6 & -4.1 & -9.1 \\
\hline Overall balance (incl. grants) & 1.3 & 10.5 & -7.1 & -5.1 & -0.1 & -2.0 \\
\hline Total financing & -1.3 & -10.5 & 7.1 & 5.1 & 0.1 & 2.0 \\
\hline External financing & 12.7 & 1.4 & 2.3 & 0.8 & 1.4 & -1.2 \\
\hline Domestic financing 4/ & -14.0 & -11.9 & 4.9 & 4.4 & -3.3 & 0.2 \\
\hline \multirow[t]{2}{*}{ Privatization receipts } & 0.0 & 0.0 & 0.0 & 0.0 & 2.0 & 3.0 \\
\hline & \multicolumn{6}{|c|}{ (In percent of GDP) } \\
\hline Total revenue and grants & 29.9 & 28.7 & 33.4 & 33.2 & 31.4 & 31.8 \\
\hline Total revenue & 28.5 & 27.4 & 31.3 & 29.8 & 29.4 & 28.6 \\
\hline Current revenue & 28.5 & 27.4 & 31.3 & 29.8 & 29.4 & 28.6 \\
\hline Tax revenue & 23.2 & 23.2 & 26.5 & 25.7 & 26.1 & 25.2 \\
\hline Nontax revenue $1 /$ & 5.3 & 4.3 & 4.7 & 4.1 & 3.2 & 3.4 \\
\hline Capital revenue & 0.0 & 0.0 & 0.0 & 0.0 & 0.0 & 0.0 \\
\hline Grants (in cash) $2 /$ & 1.4 & 1.3 & 2.1 & 3.4 & 2.0 & 3.2 \\
\hline Total expenditure and net lending & 29.5 & 26.3 & 34.9 & 34.3 & 31.4 & 32.1 \\
\hline Total expenditure & 29.8 & 26.5 & 35.1 & 34.4 & 31.4 & 31.9 \\
\hline Current expenditure & 27.3 & 25.4 & 35.0 & 32.5 & 30.1 & 30.1 \\
\hline Wages and salaries $3 /$ & 12.3 & 11.7 & 19.1 & 16.2 & 13.8 & 13.5 \\
\hline Of which: Redundancy Package & 0.0 & 0.0 & 5.1 & 0.0 & 0.0 & 0.0 \\
\hline Capital expenditure & 1.0 & 1.0 & 3.2 & 1.1 & 1.3 & 1.8 \\
\hline Expenditure discrepancy & 1.4 & 0.1 & -3.1 & 0.7 & 0.0 & 0.0 \\
\hline Total lending minus repayments & -0.3 & -0.2 & -0.3 & -0.1 & 0.0 & 0.2 \\
\hline Current balance & 1.1 & 2.0 & -3.7 & -2.8 & -0.7 & -1.5 \\
\hline Overall balance (incl. grants) & 0.3 & 2.5 & -1.5 & -1.0 & 0.0 & -0.3 \\
\hline Total financing & -0.3 & -2.5 & 1.5 & 1.0 & 0.0 & 0.3 \\
\hline External financing & 3.4 & 0.3 & 0.5 & 0.2 & 0.3 & -0.2 \\
\hline Domestic financing 4/ & -3.8 & -2.8 & 1.0 & 0.9 & -0.6 & 0.0 \\
\hline Privatization receipts & 0.0 & 0.0 & 0.0 & 0.0 & 0.4 & 0.5 \\
\hline \multicolumn{7}{|l|}{ Memorandum item: } \\
\hline Nominal GDP (in millions of pa'anga) & 371.9 & 424.8 & 474.4 & 492.7 & 554.1 & 603.6 \\
\hline Total external public debt outstanding (in percent of GDP) & 42.9 & 36.1 & 35.4 & 33.2 & 29.8 & 31.4 \\
\hline Of which: PRC Reconstruction loan 5/ & $\ldots$ & $\ldots$ & $\ldots$ & $\ldots$ & $\ldots$ & 4.2 \\
\hline
\end{tabular}

Sources: Data provided by the Tongan authorities; and Fund staff estimates.

1/ Nontax revenue for 2005/06 includes unclassified revenue of TOP3.4 million.

2/ Grants are mostly spent for other current expenditures.

3/ Wage bill for 2006/07 includes TOP 9.6 million of carryover payments from 2005/06.

4 / Includes domestic net bond financing and net changes in government cash balance and investment.

$5 /$ The loan is excluded from the government accounts. 
Table 3. Tonga: Banking Survey, 2004/05-2007/08 1/

\begin{tabular}{|c|c|c|c|c|c|c|c|c|c|c|}
\hline & \multirow[t]{2}{*}{$2004 / 05$} & \multirow[t]{2}{*}{$2005 / 06$} & \multicolumn{4}{|c|}{$2006 / 07$} & \multicolumn{4}{|c|}{$2007 / 08$} \\
\hline & & & Sep & Dec & Mar & Jun & Sep & Nov & Dec & Jan \\
\hline & \multicolumn{10}{|c|}{ (In millions of pa'anga; end of period) } \\
\hline Net foreign assets & 76.3 & 71.9 & 76.8 & 75.6 & 76.4 & 81.1 & 92.8 & 81.4 & 103.0 & 102.7 \\
\hline Foreign assets & 91.8 & 95.0 & 96.9 & 95.9 & 99.7 & 103.6 & 114.5 & 103.3 & 123.1 & 122.4 \\
\hline NRBT & 82.1 & 83.2 & 85.3 & 84.2 & 90.4 & 91.6 & 104.8 & 94.8 & 114.6 & 113.1 \\
\hline DMBs & 9.7 & 11.8 & 11.7 & 11.8 & 9.3 & 12.0 & 9.7 & 8.5 & 8.5 & 9.2 \\
\hline Foreign liabilities & -15.5 & -23.1 & -20.2 & -20.3 & -23.3 & -22.6 & -21.7 & -22.0 & -20.2 & -19.7 \\
\hline NRBT & -3.2 & -7.1 & -4.7 & -4.3 & -4.2 & -4.7 & -4.8 & -4.4 & -4.9 & -3.7 \\
\hline DMBs & -11.4 & -15.3 & -14.9 & -15.4 & -18.7 & -17.2 & -16.2 & -16.9 & -14.7 & -15.3 \\
\hline TDB & -0.9 & -0.6 & -0.6 & -0.6 & -0.4 & -0.6 & -0.6 & -0.6 & -0.6 & -0.6 \\
\hline Net domestic assets & 154.2 & 186.1 & 188.2 & 198.8 & 196.2 & 211.4 & 210.2 & 220.1 & 212.4 & 211.9 \\
\hline Net domestic credit & 210.3 & 264.5 & 279.8 & 278.1 & 277.0 & 295.2 & 307.9 & 321.8 & 306.7 & 306.4 \\
\hline Government (net) & -25.2 & -18.9 & -6.0 & -9.0 & -18.8 & -12.9 & -11.6 & -9.6 & -25.9 & -29.6 \\
\hline Nonfinancial public enterprises & 8.6 & 5.4 & 4.9 & 4.4 & 4.0 & 3.7 & 3.5 & 4.4 & 4.8 & 5.0 \\
\hline Private sector & 226.8 & 278.0 & 280.9 & 282.7 & 291.8 & 304.3 & 315.9 & 327.0 & 327.9 & 331.0 \\
\hline Other items (net) & -56.1 & -78.4 & -91.6 & -79.3 & -80.9 & -83.7 & -97.6 & -101.7 & -94.4 & -94.5 \\
\hline Total liquidity & 223.7 & 253.4 & 270.9 & 271.6 & 266.3 & 287.1 & 297.8 & 296.3 & 307.6 & 302.4 \\
\hline Broad money (M2) & 203.7 & 237.5 & 254.1 & 255.3 & 249.8 & 265.8 & 277.5 & 275.8 & 287.1 & 282.0 \\
\hline Narrow money & 68.7 & 55.7 & 64.6 & 70.1 & 68.7 & 73.8 & 79.9 & 77.7 & 78.8 & 76.3 \\
\hline Quasi money & 134.9 & 181.8 & 189.5 & 185.2 & 181.1 & 192.0 & 197.6 & 198.1 & 208.3 & 205.7 \\
\hline Notes and bills $2 /$ & 20.1 & 15.9 & 16.8 & 16.3 & 16.4 & 21.4 & 20.3 & 20.5 & 20.5 & 20.5 \\
\hline \multirow[t]{2}{*}{ Government lending funds $3 /$} & 6.8 & 6.1 & 6.0 & 5.8 & 6.4 & 5.4 & 5.3 & 5.2 & 5.2 & 5.2 \\
\hline & \multicolumn{10}{|c|}{ (Annual percent change) } \\
\hline Net foreign assets & -8.9 & -5.8 & -5.6 & -0.3 & 12.3 & 12.7 & 20.9 & 8.3 & 36.2 & 34.1 \\
\hline Net domestic assets & 27.2 & 20.7 & 13.7 & 15.9 & 12.0 & 13.6 & 11.7 & 12.9 & 6.8 & 13.9 \\
\hline Net domestic credit & 20.9 & 25.8 & 23.8 & 17.3 & 14.4 & 11.6 & 10.0 & 13.9 & 10.3 & 11.5 \\
\hline Private sector & 29.4 & 22.6 & 15.0 & 10.4 & 6.6 & 9.5 & 12.5 & 14.9 & 16.0 & 16.6 \\
\hline Total liquidity & 13.3 & 13.3 & 12.8 & 12.8 & 12.3 & 13.3 & 9.9 & 8.8 & 13.3 & 13.1 \\
\hline \multirow[t]{2}{*}{ Broad money (M2) } & 12.8 & 16.6 & 15.1 & 13.6 & 13.6 & 11.9 & 9.2 & 7.8 & 12.5 & 12.5 \\
\hline & \multicolumn{10}{|c|}{ (In millions of U.S. dollars) } \\
\hline Net foreign assets & 39.5 & 34.9 & 38.1 & 37.8 & 38.5 & 41.7 & 47.5 & 42.5 & 54.6 & 55.0 \\
\hline Foreign assets & 47.5 & 46.1 & 48.1 & 48.0 & 50.2 & 53.3 & 58.5 & 53.9 & 65.3 & 65.5 \\
\hline NRBT & 42.5 & 40.4 & 42.3 & 42.1 & 45.5 & 47.1 & 53.6 & 49.5 & 60.7 & 60.6 \\
\hline DMBs & 5.0 & 5.7 & 5.8 & 5.9 & 4.7 & 6.2 & 5.0 & 4.4 & 4.5 & 5.0 \\
\hline Foreign liabilities & -8.0 & -11.2 & -10.0 & -10.2 & -11.7 & -11.6 & -11.1 & -11.5 & -10.7 & -10.5 \\
\hline \multicolumn{11}{|l|}{ Memorandum items: } \\
\hline Velocity (GDP/average M2) & 2.2 & 2.1 & $\ldots$ & $\ldots$ & $\ldots$ & 1.9 & $\ldots$ & $\ldots$ & $\ldots$ & $\ldots$ \\
\hline Pa'anga per U.S. dollar (end of period) & 1.93 & 2.06 & 2.01 & 2.00 & 1.99 & 1.95 & 1.96 & 1.92 & 1.89 & 1.87 \\
\hline
\end{tabular}

Sources: Data provided by the Tongan authorities; and Fund staff estimates.

1/ Comprises the National Reserve Bank of Tonga (NRBT), the deposit money banks, and the Tonga Development Bank (TDB).

2/ Comprises bills and promissory notes issued by financial sector and held outside the sector.

3/ Represents borrowing by the government from foreign sources for onlending to the TDB. 
Table 4: Tonga: Balance of Payments Summary, 2003/04-2008/09 1/

(In millions of U.S. dollars, unless otherwise indicated)

\begin{tabular}{|c|c|c|c|c|c|c|}
\hline & $2003 / 04$ & $2004 / 05$ & $2005 / 06$ & 2006/07 & $2007 / 08$ & $2008 / 09$ \\
\hline & & & & & \multicolumn{2}{|c|}{ Proj. } \\
\hline Trade balance & -68.8 & -89.3 & -106.7 & -95.3 & -120.2 & -138.8 \\
\hline Exports, f.o.b. & 13.8 & 16.0 & 15.4 & 13.3 & 14.8 & 15.5 \\
\hline (Annual percent change) & -21.2 & 16.0 & -3.8 & -13.6 & 11.1 & 4.9 \\
\hline Imports, f.o.b. & -82.6 & -105.4 & -122.2 & -108.6 & -135.0 & -154.3 \\
\hline (Annual percent change) & 11.3 & 27.5 & 15.9 & -11.1 & 24.3 & 14.3 \\
\hline Services (net) & -2.8 & -10.0 & -7.8 & -17.9 & -14.4 & -13.6 \\
\hline Receipts & 25.8 & 23.7 & 25.3 & 19.4 & 24.8 & 29.2 \\
\hline Payments & -28.6 & -33.6 & -33.2 & -37.3 & -39.2 & -42.8 \\
\hline Investment income (net) & -0.4 & 1.6 & 2.8 & 3.5 & 3.7 & 3.6 \\
\hline Receipts & 2.7 & 3.4 & 4.9 & 6.4 & 8.0 & 8.5 \\
\hline Payments & -3.1 & -1.8 & -2.1 & -2.9 & -4.3 & -4.8 \\
\hline Current transfers (net) & 79.7 & 91.9 & 88.9 & 84.2 & 104.1 & 126.0 \\
\hline Official transfers (net) & 0.3 & 0.0 & 0.0 & 0.0 & 0.3 & 0.5 \\
\hline Private transfers (net) & 79.4 & 91.9 & 88.9 & 84.2 & 103.8 & 125.5 \\
\hline Current account balance & 7.7 & -5.8 & -22.8 & -25.5 & -26.8 & -22.8 \\
\hline (In percent of GDP) & 4.2 & -2.6 & -9.7 & -10.4 & -10.4 & -8.8 \\
\hline Capital and financial account balance & 37.0 & 12.5 & 22.5 & 26.9 & 27.7 & 25.3 \\
\hline Official capital flows (net) & 13.7 & 4.8 & 8.4 & 9.8 & 7.3 & 5.3 \\
\hline Private capital flows (net) & 23.2 & 7.7 & 14.1 & 17.1 & 20.5 & 20.1 \\
\hline Errors and omissions & -18.8 & -10.7 & 1.0 & 2.7 & -4.7 & 0.0 \\
\hline Overall balance $2 /$ & 25.9 & -4.0 & 0.6 & 4.2 & -3.7 & 2.6 \\
\hline \multicolumn{7}{|l|}{ Memorandum items: } \\
\hline Gross official foreign reserves & 44.8 & 42.5 & 40.4 & 47.1 & 43.4 & 46.0 \\
\hline In months of goods and services imports $3 /$ & 4.8 & 3.7 & 3.1 & 3.9 & 3.0 & 2.8 \\
\hline \multicolumn{7}{|l|}{ Exchange rate } \\
\hline Pa'anga per U.S. dollar (period average) & 2.05 & 1.94 & 2.01 & 2.00 & 2.15 & 2.29 \\
\hline Pa'anga per U.S. dollar (end of period) & 2.00 & 1.93 & 2.06 & 1.95 & 2.07 & 2.22 \\
\hline Nominal GDP & 181.8 & 219.1 & 236.2 & 246.0 & 258.3 & 258.8 \\
\hline \multicolumn{7}{|l|}{ Commodity price indexes $(2005=100)$} \\
\hline Food & 94.8 & 100.5 & 105.2 & 118.9 & 138.9 & 149.8 \\
\hline Fuel & 63.8 & 86.2 & 109.6 & 125.5 & 163.2 & 181.7 \\
\hline
\end{tabular}

Source: Data provided by the Tongan authorities; and Fund staff estimates.

$1 /$ Excludes reconstruction loan.

$2 /$ Change in gross official foreign reserves.

$3 /$ The current year's imports. 
Table 5. Tonga: Medium-Term Scenario, 2005/06-2012/13 1/

\begin{tabular}{|c|c|c|c|c|c|c|c|c|}
\hline & $2005 / 06$ & $2006 / 07$ & $2007 / 08$ & $2008 / 09$ & $2009 / 10$ & 2010/11 & $2011 / 12$ & $2012 / 13$ \\
\hline & \multicolumn{2}{|c|}{ Prel. } & \multicolumn{6}{|c|}{ Proj. } \\
\hline & & & & nual perce & th change) & & & \\
\hline \multicolumn{9}{|l|}{ Output and prices } \\
\hline Real GDP & 0.6 & -3.2 & 1.2 & 2.6 & 1.9 & 1.8 & 1.6 & 1.6 \\
\hline Consumer prices (end of period) & 7.0 & 5.1 & 14.5 & 12.3 & 6.1 & 5.2 & 4.8 & 4.2 \\
\hline & \multicolumn{8}{|c|}{ (In percent of GDP) } \\
\hline \multicolumn{9}{|l|}{ Central government finance } \\
\hline Total revenue and grants & 33.4 & 33.2 & 31.4 & 31.8 & 32.0 & 32.1 & 32.2 & 32.3 \\
\hline Total revenue & 31.3 & 29.8 & 29.4 & 28.6 & 28.6 & 28.6 & 28.6 & 28.6 \\
\hline Grants & 2.1 & 3.4 & 2.0 & 3.2 & 3.3 & 3.4 & 3.5 & 3.6 \\
\hline Total expenditure and net lending & 34.9 & 34.3 & 31.4 & 32.1 & 31.9 & 32.0 & 32.0 & 32.1 \\
\hline Current expenditure & 35.0 & 32.5 & 30.1 & 30.1 & 29.8 & 29.8 & 29.6 & 29.6 \\
\hline Capital expenditure & 3.2 & 1.1 & 1.3 & 1.8 & 1.9 & 2.0 & 2.2 & 2.3 \\
\hline Expenditure discrepancy & -3.1 & 0.7 & $\ldots$ & $\ldots$ & $\ldots$ & $\ldots$ & $\ldots$ & $\ldots$ \\
\hline Net lending & -0.3 & -0.1 & 0.0 & 0.2 & 0.2 & 0.2 & 0.2 & 0.2 \\
\hline Overall balance & -1.5 & -1.0 & 0.0 & -0.3 & 0.0 & 0.0 & 0.1 & 0.1 \\
\hline External financing (net) & 0.5 & 0.2 & 0.3 & -0.2 & 0.0 & -0.2 & -0.1 & 0.0 \\
\hline Domestic financing (net) & 1.0 & 0.9 & -0.6 & 0.0 & -0.1 & 0.2 & 0.0 & -0.2 \\
\hline Privatization receipts & 0.0 & 0.0 & 0.4 & 0.5 & 0.0 & 0.0 & 0.0 & 0.0 \\
\hline & \multicolumn{8}{|c|}{ (In millions of U.S. dollars) } \\
\hline \multicolumn{9}{|l|}{ Balance of payments } \\
\hline Exports, f.o.b. & 15.4 & 13.3 & 14.8 & 15.5 & 16.7 & 17.8 & 18.9 & 20.0 \\
\hline (Annual percent change) & -3.8 & -13.6 & 11.1 & 4.9 & 7.5 & 6.8 & 6.2 & 5.7 \\
\hline Imports, f.o.b. & -122.2 & -108.6 & -135.0 & -154.3 & -164.6 & -167.6 & -177.9 & -188.1 \\
\hline (Annual percent change) & 15.9 & -11.1 & 24.3 & 14.3 & 6.7 & 1.8 & 6.2 & 5.7 \\
\hline Services and investment income (net) & -5.0 & -14.4 & -10.7 & -10.0 & -11.1 & -9.5 & -10.1 & -10.7 \\
\hline Transfers (net) & 88.9 & 84.2 & 104.1 & 126.0 & 134.9 & 136.7 & 145.2 & 153.5 \\
\hline Of which: Private transfer receipts & 102.0 & 93.3 & 116.5 & 138.8 & 148.7 & 151.4 & 160.7 & 169.9 \\
\hline (Annual percent change) & -5.0 & -8.6 & 24.9 & 19.1 & 7.1 & 1.8 & 6.2 & 5.7 \\
\hline Current account balance & -22.8 & -25.5 & -26.8 & -22.8 & -24.0 & -22.6 & -23.9 & -25.3 \\
\hline (In percent of GDP) & -9.7 & -10.4 & -10.4 & -8.8 & -8.7 & -7.6 & -7.6 & -7.6 \\
\hline Capital account balance & 22.5 & 26.9 & 27.7 & 25.3 & 26.9 & 28.6 & 30.5 & 32.5 \\
\hline Official capital flows (net) & 8.4 & 9.8 & 7.3 & 5.3 & 5.7 & 5.9 & 6.4 & 7.0 \\
\hline Private capital flows (net) & 14.1 & 17.1 & 20.5 & 20.1 & 21.2 & 22.6 & 24.0 & 25.4 \\
\hline Overall balance & 0.6 & 4.2 & -3.7 & 2.6 & 2.9 & 6.0 & 6.6 & 7.2 \\
\hline \multicolumn{9}{|l|}{ Gross international reserves (end of period) } \\
\hline In millions of U.S. dollars & 40.4 & 47.1 & 43.4 & 46.0 & 48.8 & 54.8 & 61.4 & 68.6 \\
\hline In months of imports (goods and services) & 3.1 & 3.9 & 3.0 & 2.8 & 2.8 & 3.1 & 3.2 & 3.4 \\
\hline \multicolumn{9}{|l|}{ External debt } \\
\hline Public sector external debt (in percent of GDP) & 35.4 & 33.2 & 29.8 & 31.4 & 35.7 & 36.8 & 37.7 & 38.7 \\
\hline Of which: PRC Reconstruction loan & & & 0.0 & 4.2 & 8.0 & 11.5 & 14.6 & 17.6 \\
\hline Debt service ratio $2 /$ & 7.5 & 9.8 & 11.0 & 10.5 & 9.3 & 10.7 & 10.3 & 9.5 \\
\hline Of which: PRC Reconstruction loan & $\ldots$ & $\ldots$ & 0.0 & 0.2 & 0.3 & 0.3 & 0.3 & 0.3 \\
\hline \multicolumn{9}{|l|}{ Memorandum items: } \\
\hline Private transfers (net, in millions of U.S. dollars) & 88.9 & 84.2 & 103.8 & 125.5 & 134.4 & 136.1 & 144.5 & 152.8 \\
\hline (In percent of imports, goods and services) & 57.2 & 57.7 & 59.6 & 63.7 & 63.8 & 63.5 & 63.5 & 63.5 \\
\hline \multicolumn{9}{|l|}{ Commodity price indexes $(2005=100)$} \\
\hline Food & 105.2 & 118.9 & 138.9 & 149.8 & 147.9 & 145.2 & 142.5 & 139.4 \\
\hline Fuel & 109.6 & 125.5 & 163.2 & 181.7 & 180.3 & 178.2 & 177.4 & 176.9 \\
\hline
\end{tabular}

Sources: Data provided by the Tongan authorities; and Fund staff estimates and projections.

1/ Fiscal year beginning July.

$2 /$ In percent of exports of goods and services. 
Table 6. Tonga: Banking Sector Indicators, 2003-07 1/

(In percent; end of period)

\begin{tabular}{|c|c|c|c|c|c|}
\hline & 2003 & 2004 & 2005 & 2006 & 2007 \\
\hline \multicolumn{6}{|l|}{ Capital adequacy } \\
\hline Risk-weighted capital ratio & 21.9 & 23.9 & 19.7 & 21.3 & 22.5 \\
\hline Total capital to total assets & 18.5 & 16.3 & 16.3 & 17.3 & 19.1 \\
\hline \multicolumn{6}{|l|}{ Asset quality } \\
\hline Nonperforming loan to total loans & 9.6 & 5.9 & 4.2 & 3.7 & 5.3 \\
\hline Nonperforming loans to capital & 39.1 & 24.4 & 20.2 & 16.1 & 21.6 \\
\hline Nonperforming loans net of provisions to total capital & 14.2 & 0.1 & 3.0 & 0.6 & 3.8 \\
\hline \multicolumn{6}{|l|}{ Profitability } \\
\hline Return on assets & 5.8 & 6.0 & 6.6 & 5.4 & 4.6 \\
\hline Return on equity & 23.0 & 22.1 & 24.9 & 21.5 & 18.0 \\
\hline Net interest margin & 8.7 & 10.0 & 8.6 & 8.1 & 8.1 \\
\hline Net interest income to gross income & 61.2 & 61.1 & 60.5 & 60.3 & 54.0 \\
\hline \multicolumn{6}{|l|}{ Other } \\
\hline Risk concentration ratio $2 /$ & 35.9 & 17.7 & 11.5 & 17.1 & 16.6 \\
\hline Share of loans to nonfinancial corporations $3 /$ & 50.9 & 39.6 & 37.3 & 43.8 & 48.9 \\
\hline
\end{tabular}

Sources: Data provided by the Tongan authorities; and Fund staff estimates.

1/ Include the Tonga Development Bank.

2/ For commercial banks, the data are defined as the share of the largest 10 loans in total loans.

$3 /$ Includes commercial banks. 


\title{
INTERNATIONAL MONETARY FUND AND \\ INTERNATIONAL DEVELOPMENT ASSOCIATION
}

\author{
TONGA
}

\section{Joint IMF/World Bank Debt Sustainability Analysis 2008'}

Prepared by the staffs of the International Monetary Fund and

The International Development Association

Approved by Jeremy V. Carter and Anthony Boote (IMF) and Vikram Nehru and Carlos Primo Braga (IDA)

June 17, 2008

Under the baseline scenario, the NPV-of-debt to GDP as well as the NPV-of-debt to export ratios remain above the country-specific indicative thresholds for a prolonged period. Consequently, the Low Income Country Debt Sustainability Analysis (LIC DSA) indicates that Tonga remains at a high risk of external debt distress. At the same time, Tonga benefits from very high remittance inflows (over 30 percent of GDP), which are by far the largest source of foreign exchange earnings and have a countervailing effect by helping to mitigate liquidity risks. Moreover, Tonga's overall public sector debt indicators, while elevated over the short term, show a decreasing trend over the longer run. Taking into account the cushion provided to the economy by the large workers remittances, the debt should remain manageable.

The LIC DSA suggests limiting the utilization of the nonconcessional reconstruction loan while lengthening its disbursement horizon, together with increases in donor grant and concessional financing to support future developments, are crucial for further improving Tonga's public debt dynamics. Fiscal prudence and policies to enhance growth prospects are also critical underpinnings to debt sustainability over the medium term.

\footnotetext{
${ }^{1}$ This DSA was prepared jointly with the World Bank in accordance with the Debt Sustainability Framework for low-income countries approved by the Executive Boards of the IMF and IDA. The debt data underlying this exercise were provided by the Tongan authorities.
} 


\section{BACKGROUND}

The external and public debt sustainability analyses are based on the standard LIC DSA framework. ${ }^{2}$ The DSA presents the projected path of Tonga's external and public sector debt burden indicators, and draws some conclusions on the forward-looking sustainability of debt.

Tonga's total public sector debt stock (including publicly guaranteed debt) declined to 45 $\frac{1}{4}$ percent of GDP in FY06/07 from 48 $1 / 2$ percent of GDP in FY05/06. External debt to GDP fell as donor financing declined in real terms, while fiscal consolidation to limit domestic budget financing also contributed to a downward trend in domestic public debt to GDP.

Following the civil unrest in November of 2006, the government made a significant effort toward securing financing for the reconstruction of the capital city of Nuku'alofa. This includes donor grants of about $\$ 15$ million, to be channeled through designated banks to business entities affected by the riots in the form of off-budget, low interest rate loans in the second half of FY07/08. The government also signed a long-term reconstruction loan from the EXIM Bank of China in November 2007. Disbursements of this loan have been postponed, as the government is currently reassessing the overall financing requirement for the reconstruction, with an aim to reduce the overall loan utilization and lengthening the disbursement horizon. ${ }^{3}$

\section{BASELine}

Tonga's DSA builds on the baseline scenario assumptions presented in Box 1. It assumes real GDP growth rate at its historical average, fiscal consolidation, a utilization of $\$ 50$ million of the reconstruction loan over FY08/09-FY12/13, with an even disbursement of $\$ 10$ million per year and repayments after a five-year grace period. The baseline assumes no other major external nonconcessional borrowing. The authorities are currently reassessing the overall financing requirement to be supported by the reconstruction loan, with an aim to significantly reduce the overall size of loan utilization while lengthening the disbursement horizon. Accordingly, the assumption on the reconstruction loan under the baseline is likely to be an upper bound.

\footnotetext{
${ }^{2}$ See "Debt Sustainability in Low-Income Countries: Proposal for an Operational Framework and Policy Implications" (http://www.imf.org/external/np/pdr/sustain/2004/020304.htm and IDA/SECM2004/0035, 2/3/04), "Debt Sustainability in Low-Income Countries: Further Considerations on an Operational Framework and Policy Implications" (http://www.imf.org/external/np/pdr/sustain/2004/091004.htm and IDA/SECM2004/0629, 9/10/04), and reference to "Staff Guidance Note on the Application of the Joint BankFund Debt Sustainability."

${ }^{3}$ The 2008 DSA baseline shows an improved public debt and debt service profiles over the medium to long term as compared with those presented in the 2007 DSA where the reconstruction loan was assumed to be disbursed and utilized fully over a two-year period during FY08/09-09/10.
} 


\begin{tabular}{|c|c|c|c|}
\hline \multicolumn{4}{|c|}{ Tonga: Baseline Vis-a-Vis 10-year Average (used in the DSA) } \\
\hline & $\begin{array}{c}\text { Baseline } \\
2007 / 08-2012 / 13\end{array}$ & $2013 / 14-2028 / 29$ & $\begin{array}{c}10 \text {-year } \\
\text { Historical } \\
\text { Average } \\
1997 / 98-2006 / 0\end{array}$ \\
\hline Real GDP growth (in percent) & 1.8 & 1.6 & 1.9 \\
\hline GDP deflator (in U.S. dollar term, change in percent) & 3.3 & 2.1 & 2.2 \\
\hline Current account deficit (percent of GDP) & -8.4 & -7.7 & -4.4 \\
\hline Growth of exports of G\&S (U.S. dollar, in percent) & 9.9 & 3.9 & -1.2 \\
\hline Overall fiscal balance (percent of GDP) & 0.0 & 0.1 & -0.7 \\
\hline
\end{tabular}

\section{EXTERNAL DSA}

External debt declined to $401 / 2$ percent of GDP in FY06/07, from 42 $1 / 2$ percent of GDP in FY05/06, over 80 percent of which is on concessional terms. Under the baseline scenario, the NPV of PPG external debt is projected to increase by about 5 percent of GDP, to 38 percent of GDP by FY12/13, above its indicative threshold of 30 percent, but decline subsequently to $161 / 2$ percent of GDP by FY27/28. ${ }^{4}$ The NPV of debt and debt service-torevenue ratios also remain well below their respective indicative thresholds of 200 percent and 25 percent over the projection period (Table 1a).

\section{Reflecting Tonga's low exports, the NPV of PPG external debt-to-exports ratio is} projected to exceed the respective indicative threshold of 100 percent. However, this is mitigated by the fact that large remittances, which are the largest source of foreign exchange earnings (one half of Tongans live abroad, mostly in Australia, New Zealand, and the United States) have a countervailing effect by helping to reduce liquidity risks. ${ }^{5}$ Efforts to improve the policy framework, including fiscal consolidation, will also be critical to reduce risks of external debt distress.

\footnotetext{
${ }^{4}$ The average World Bank's Country Policy and Institutional Assessment for the period 2005-2007 classifies Tonga as a poor performer. The corresponding debt distress thresholds are: NPV of debt-to-exports (100 percent), GDP (30 percent), and revenues (200 percent); and debt service in percent of exports (15 percent) and revenues (25 percent).

${ }^{5}$ The baseline scenario assumes that net private transfer receipts will climb to an average $45 \frac{1}{2}$ percent of GDP over the projection period from a historical average of $33 \frac{1}{2}$ percent, mainly reflecting the recent increase in the number of Tongan workers abroad as well as a reduction in transfer costs.
} 
Tonga: External Public Debt Indicators

Indicative Thresholds 1/

$2006 / 07$

NPV of external debt

In percent of GDP

In percent of exports

30

204

In percent of revenues

200

Debt service

In percent of exports

15

In percent of revenues

25

11

5

1/ Represents Low Income Country DSA indicative thresholds for Tonga that is classified as a poor performer under the World Bank's Country Policy and Institutional assessment.

The alternative scenarios and bound tests indicate Tonga's vulnerability of its external debt position to negative shocks to remittances and exports (Table 1b, Figure 1). Stress tests also underscore the importance of limiting the nonconcessional borrowing to reduce the risk without undermining debt sustainability. Moreover, a return of key variables, including GDP and export growth, to their historical averages, would imply a deterioration in all ratios.

\section{Public Debt Sustainability Analysis}

Tonga's public debt sustainability depends critically on fiscal prudence, the government's commitment to limit new public borrowing, and its adoption of a phased approach to utilizing the reconstruction loan (Table 2a). Under the baseline scenario, total NPV of public debt is projected to increase by 5 percent of GDP by 2012/13 (to 43 percent of GDP), and gradually decline to about 18 percent of GDP over the longer term, benefiting in part from a favorable fiscal policy stance under the baseline scenario. Domestic public debt is also projected to narrow markedly under this scenario, in line with recent policy commitments, to below 6 percent of GDP by 2012/13 and less than 1 percent of GDP by $2027 / 28$.

Alternative scenarios and stress tests highlight the vulnerability of the total public debt to growth shocks, which could lead to a sharp deterioration in the debt burden indicators. Furthermore, if other debt-creating flows increase, or the primary fiscal deficit returns to its historical average of 0.6 percent of GDP, the public debt dynamics would become much less favorable. The size of the reconstruction loan also remains a key risk, especially if it were to be fully disbursed in the next two years (FY08/09-09/10), as originally planned. 


\section{Staff Assessment}

Tonga remains at a high risk of external debt distress. At the same time, Tonga benefits from very high remittance inflows, which are the largest source of foreign exchange earnings and have a countervailing effect by helping to mitigate liquidity risks. Moreover, Tonga's overall public sector debt dynamics, while elevated over the short term, shows a decreasing trend over the longer run, suggesting that it should remain manageable.

\section{Stress tests highlight key vulnerabilities to debt sustainability over the medium term, including lower GDP growth, major external shocks, and borrowing on less \\ concessional terms. This underscores the importance of sound macroeconomic policies to improve growth potential on a sustainable basis, export diversification, and continued efforts in fiscal consolidation. Moreover, limited use of nonconcessional borrowing and increased utilization of donor grants and concessional financing would substantially improve the public debt dynamics and reduce the risk of external debt distress. A sound public debt policy, in line with the medium-term fiscal framework, is also essential to guide future development financing in Tonga. In this context, priorities should be given to projects which would help generate high growth and employment to ensure debt service capacity in the future.}




\section{Box 1. Baseline Assumptions}

Real GDP growth is projected to average $13 / 4$ percent over the period 2007/08-2012/13. This reflects a transitory growth stimulus spurred by reconstruction activity in the capital city over the first two years, and a return to a historical average of $1 \frac{1}{2}$ percent thereafter. This conservative long-run growth outlook reflects structural impediments which continue to constrain Tonga's growth potential.

Inflation, as measured by the GDP deflator, is projected to average at around 8 percent over the projection period of 2007/08-2012/13, reflecting partial pass through of world food and fuel price increases assumed by the WEO. In U.S. dollar terms, GDP deflator inflation is projected to average around 4 percent over the same period, reflecting modest depreciation of the pa'anga against the U.S. dollar.

The fiscal balance is projected to achieve a virtual balance during 2007/08-2008/09 and small surpluses over 2009/10-2012/13, based on the authorities' stated objectives to limit domestic financing of the budget. In the long run, tax revenue is projected to stabilize near its historical average of around 32 percent of GDP, while total expenditure to come slightly below its historical average of 32 percent of GDP through a modest containment of the wage bill in real terms. This implies a fiscal surplus of $1 / 4$ percent of GDP in the long run to build fiscal savings.

The current account deficit is projected to narrow to about 7 percent of GDP over the medium term and stabilize around that level thereafter (from 10 percent of GDP in 2007/08). Export base is projected to remain narrow and relatively undiversified, while strong remittance inflows are expected to continue. Growth of imports is projected to moderate markedly as reconstruction-related imports subside and world food and fuel prices stabilize. Meanwhile, the outlook for net foreign direct investment remains favorable, broadly in line with the past five-year average of 5 $\frac{1}{2}$ percent of GDP. Official foreign reserves are projected to remain comfortable in terms of import cover.

Reconstruction financing under the baseline represents an illustrative scenario where a softloan of about $\$ 10$ million per year would be disbursed over a five-year period during 2008/09-2012/13. The cumulative loan disbursement of about $\$ 50$ million represents a plausible upper bound on the utilization of the $\$ 63$ million reconstruction loan over the next five years. This loan has an interest rate of 2 percent and a maturity of 20 years, with a 5-year grace period. 





Table 1b. Tonga: Sensitivity Analyses for Key Indicators of Public and Publicly Guaranteed External Debt, 2007/08-2027/28 (In percent)

NPV of debt-to-GDP ratio

Baseline

A. Alternative Scenarios

A1. Key variables at their historical averages in 2008/09-27/28 1/ A2. New public sector loans on less favorable terms in 2008/09-27/28 2/

\section{B. Bound Tests}

B1. Real GDP growth at historical average minus one standard deviation in 2008/09-09/10 B2. Export value growth at historical average minus one standard deviation in 2008/09-09/10 3/ B3. US dollar GDP deflator at historical average minus one standard deviation in 2008/09-09/10 B4. Net non-debt creating flows at historical average minus one standard deviation in 2008/09-09/10 4

B5. Combination of B1-B4 using one-half standard deviation shocks

B6. One-time 30 percent nominal depreciation relative to the baseline in 2008/09 5/

$\begin{array}{llllllll}26 & 29 & 32 & 34 & 36 & 38 & 30 & 17 \\ & & & & & & & \\ 26 & 29 & 33 & 36 & 39 & 43 & 38 & 29 \\ 26 & 31 & 35 & 39 & 43 & 46 & 41 & 31 \\ & & & & & & & \\ & & & & & & & \\ 26 & 31 & 34 & 37 & 39 & 41 & 32 & 18 \\ 26 & 32 & 39 & 41 & 42 & 44 & 37 & 20 \\ 26 & 32 & 40 & 42 & 44 & 47 & 37 & 20 \\ 26 & 44 & 61 & 62 & 63 & 65 & 57 & 32 \\ 26 & 42 & 64 & 65 & 67 & 69 & 60 & 33 \\ 26 & 42 & 47 & 49 & 52 & 55 & 44 & 24\end{array}$

NPV of debt-to-exports ratio

\section{Baseline}

\section{A. Alternative Scenarios}

A1. Key variables at their historical averages in 2008/09-27/28 1/ A2. New public sector loans on less favorable terms in 2008/09-27/28 2/

\section{B. Bound Tests}

B1. Real GDP growth at historical average minus one standard deviation in 2008/09-09/10

B2. Export value growth at historical average minus one standard deviation in 2008/09-09/10 $3 /$

B3. US dollar GDP deflator at historical average minus one standard deviation in 2008-09

B4. Net non-debt creating flows at historical average minus one standard deviation in 2008/09-09/10 4 /

B5. Combination of B1-B4 using one-half standard deviation shocks

B6. One-time 30 percent nominal depreciation relative to the baseline in 2008/09 5/

$\begin{array}{rrrrrrrr}174 & 173 & 190 & 201 & 212 & 224 & 178 & 97 \\ & & & & & & & \\ 174 & 169 & 191 & 212 & 232 & 251 & 224 & 171 \\ 174 & 179 & 208 & 231 & 252 & 273 & 242 & 181 \\ & & & & & & & \\ & & & & & & & \\ 174 & 173 & 190 & 201 & 212 & 224 & 178 & 97 \\ 174 & 274 & 459 & 480 & 500 & 522 & 431 & 236 \\ 174 & 173 & 190 & 201 & 212 & 224 & 178 & 97 \\ 174 & 259 & 359 & 366 & 373 & 382 & 336 & 186 \\ 174 & 304 & 514 & 527 & 539 & 554 & 483 & 266 \\ 174 & 173 & 190 & 201 & 212 & 224 & 178 & 97\end{array}$

NPV of debt-to-revenue ratio

Baseline

\begin{tabular}{rrrrrrrr}
89 & 103 & 113 & 120 & 126 & 133 & 106 & 58 \\
& & & & & & & \\
89 & 100 & 114 & 126 & 138 & 149 & 133 & 102 \\
89 & 107 & 124 & 137 & 150 & 162 & 144 & 108 \\
& & & & & & & \\
& & & & & & & \\
89 & 107 & 120 & 128 & 135 & 142 & 113 & 62 \\
89 & 112 & 136 & 142 & 148 & 155 & 128 & 70 \\
89 & 110 & 139 & 148 & 155 & 164 & 131 & 71 \\
89 & 154 & 213 & 218 & 222 & 227 & 200 & 110 \\
89 & 146 & 223 & 229 & 234 & 241 & 210 & 116 \\
89 & 148 & 163 & 173 & 182 & 192 & 153 & 83 \\
& & & & & & & \\
\hline
\end{tabular}

A1. Key variables at their historical averages in 2008/09-27/28 1/ A2. New public sector loans on less favorable terms in 2008/09-27/28 2/

\section{B. Bound Tests}

B1. Real GDP growth at historical average minus one standard deviation in 2008/09-09/10 B2. Export value growth at historical average minus one standard deviation in 2008/09-09/10 $3 /$

B3. US dollar GDP deflator at historical average minus one standard deviation in 2008/09-09/10

B4. Net non-debt creating flows at historical average minus one standard deviation in 2008/09-09/10 4

B5. Combination of B1-B4 using one-half standard deviation shocks

B6. One-time 30 percent nominal depreciation relative to the baseline in 2008/09 5/

Source: Staff projections and simulations.

1/ Variables include real GDP growth, growth of GDP deflator (in U.S. dollar terms), non-interest current account in percent of GDP, and non-debt creating flows.

2/ Assumes that the interest rate on new borrowing is 2 percentage points higher than in the baseline, while grace and maturity periods are the same as in the baseline.

3 / Exports values are assumed to remain permanently at the lower level, but the current account as a share of GDP is assumed to return to its baseline level after the shock (implicitly assuming an offsetting adjustment in import levels).

4/ Includes official and private transfers and FDI.

5/ Depreciation is defined as percentage decline in dollar/local currency rate, such that it never exceeds 100 percent.

6/ Applies to all stress scenarios except for A2 (less favorable financing) in which the terms on all new financing are as specified in footnote 2 . 


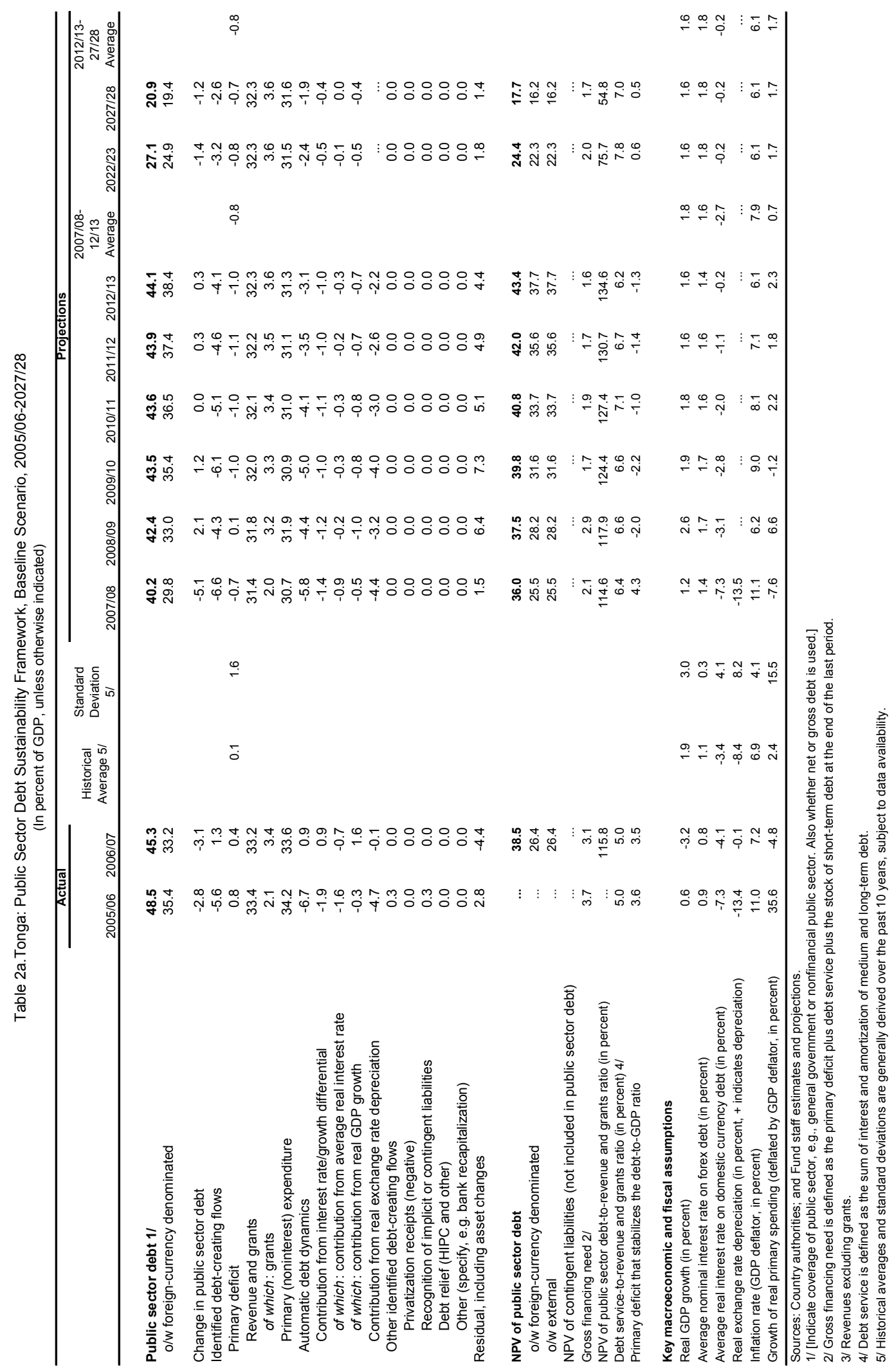


Table 2b.Tonga: Sensitivity Analysis for Key Indicators of Public Debt 2007/08-2027/28

Baseline
A. Alternative scenarios
A1. Real GDP growth and primary balance are at historical averages
A2. Primary balance is unchanged from 2007/08
A3. Permanently lower GDP growth $1 /$
B. Bound tests
B1. Real GDP growth is at historical average minus one standard deviations in 2008/09-2009/10
B2. Primary balance is at historical average minus one standard deviations in 2008/09-2009/10
B3. Combination of B1-B2 using one half standard deviation shocks
B4. One-time 30 percent real depreciation in 2008/09
B5. 10 percent of GDP increase in other debt-creating flows in 2008/09

Projections

2007/08 2008/09 2009/10 2010/112011/12 2012/132017/18 2027/28

NPV of Debt-to-Revenue Ratio 2

Baseline

A. Alternative scenarios

A1. Real GDP growth and primary balance are at historical averages A2. Primary balance is unchanged from $2007 / 08$

A3. Permanently lower GDP growth $1 /$

\section{B. Bound tests}

B1. Real GDP growth is at historical average minus one standard deviations in 2008/09-2009/10 B2. Primary balance is at historical average minus one standard deviations in 2008/09-2009/10 B3. Combination of B1-B2 using one half standard deviation shocks

B4. One-time 30 percent real depreciation in $2008 / 09$

B5. 10 percent of GDP increase in other debt-creating flows in 2008/09

Debt Service-to-Revenue Ratio 2 I

Baseline

\section{A. Alternative scenarios}

A1. Real GDP growth and primary balance are at historical averages A2. Primary balance is unchanged from $2007 / 08$

A3. Permanently lower GDP growth 1

\section{B. Bound tests}

B1. Real GDP growth is at historical average minus one standard deviations in 2008/09-2009/10 B2. Primary balance is at historical average minus one standard deviations in 2008/09-2009/10 B3. Combination of B1-B2 using one half standard deviation shocks

B4. One-time 30 percent real depreciation in 2008/09

B5. 10 percent of GDP increase in other debt-creating flows in 2008/09

Sources: Country authorities; and Fund staff estimates and projections.

$1 /$ Assumes that real GDP growth is at baseline minus one standard deviation divided by the square root of 20 (i.e., the length of the projection period). 2/ Revenues are defined inclusive of grants.

$\begin{array}{rrrrrrrr}36 & 37 & 40 & 41 & 42 & 43 & 33 & 18 \\ & & & & & & & \\ 36 & 38 & 41 & 43 & 45 & 47 & 39 & 26 \\ 36 & 37 & 39 & 41 & 42 & 44 & 34 & 19 \\ 36 & 38 & 41 & 43 & 45 & 47 & 44 & 48 \\ & & & & & & & \\ & & & & & & & \\ 36 & 40 & 45 & 48 & 51 & 54 & 49 & 40 \\ 36 & 39 & 44 & 44 & 45 & 47 & 35 & 19 \\ 36 & 39 & 44 & 45 & 46 & 47 & 35 & 18 \\ 36 & 46 & 47 & 47 & 48 & 49 & 36 & 17 \\ 36 & 47 & 48 & 49 & 49 & 50 & 38 & 20 \\ & & & & & & & \\ & & & & & & & \\ 115 & 118 & 124 & 127 & 131 & 135 & 102 & 55 \\ & & & & & & & \\ & & & & & & & \\ 115 & 119 & 129 & 134 & 140 & 146 & 123 & 82 \\ 115 & 116 & 123 & 127 & 131 & 136 & 106 & 57 \\ 115 & 119 & 128 & 133 & 139 & 146 & 135 & 148 \\ & & & & & & & \\ & & & & & & & \\ 115 & 125 & 141 & 149 & 157 & 166 & 150 & 122 \\ 115 & 123 & 137 & 139 & 141 & 145 & 110 & 58 \\ 115 & 123 & 136 & 139 & 141 & 145 & 109 & 56 \\ 115 & 144 & 147 & 148 & 150 & 153 & 110 & 52 \\ 115 & 147 & 151 & 152 & 153 & 156 & 118 & 62 \\ & & & & & & & \end{array}$

$\begin{array}{llllllll}6 & 7 & 7 & 7 & 7 & 6 & 9 & 7\end{array}$

$\begin{array}{rrrrrrrr}6 & 7 & 7 & 8 & 8 & 8 & 11 & 10 \\ 6 & 7 & 6 & 7 & 7 & 7 & 9 & 7 \\ 6 & 7 & 7 & 8 & 8 & 8 & 13 & 18\end{array}$

\begin{tabular}{rrrrrrrr}
6 & 7 & 8 & 10 & 10 & 10 & 14 & 15 \\
6 & 7 & 8 & 11 & 8 & 7 & 9 & 8 \\
6 & 7 & 8 & 10 & 8 & 7 & 9 & 7 \\
6 & 7 & 7 & 8 & 8 & 7 & 10 & 8 \\
6 & 7 & 17 & 11 & 9 & 8 & 10 & 8 \\
\hline
\end{tabular}


Figure 1. Tonga: Indicators of Public and Publicly Guaranteed External Debt Under Alternative Scenarios, 2007/08-2027/28
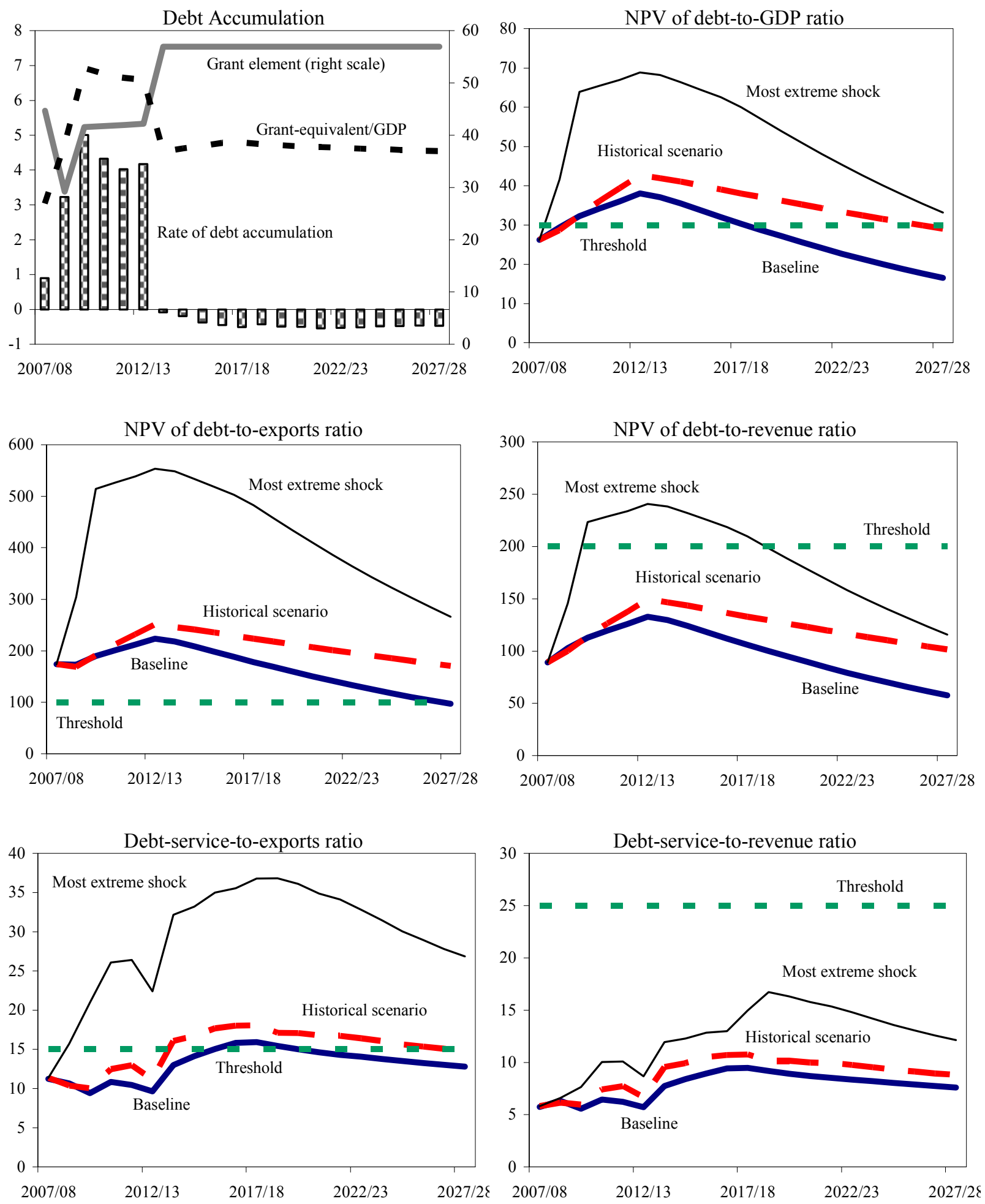

Source: Staff projections and simulations. 
Figure 2. Tonga: Indicators of Total Public Debt Under Alternative Scenarios, 2007/08-2027/28 $1 /$
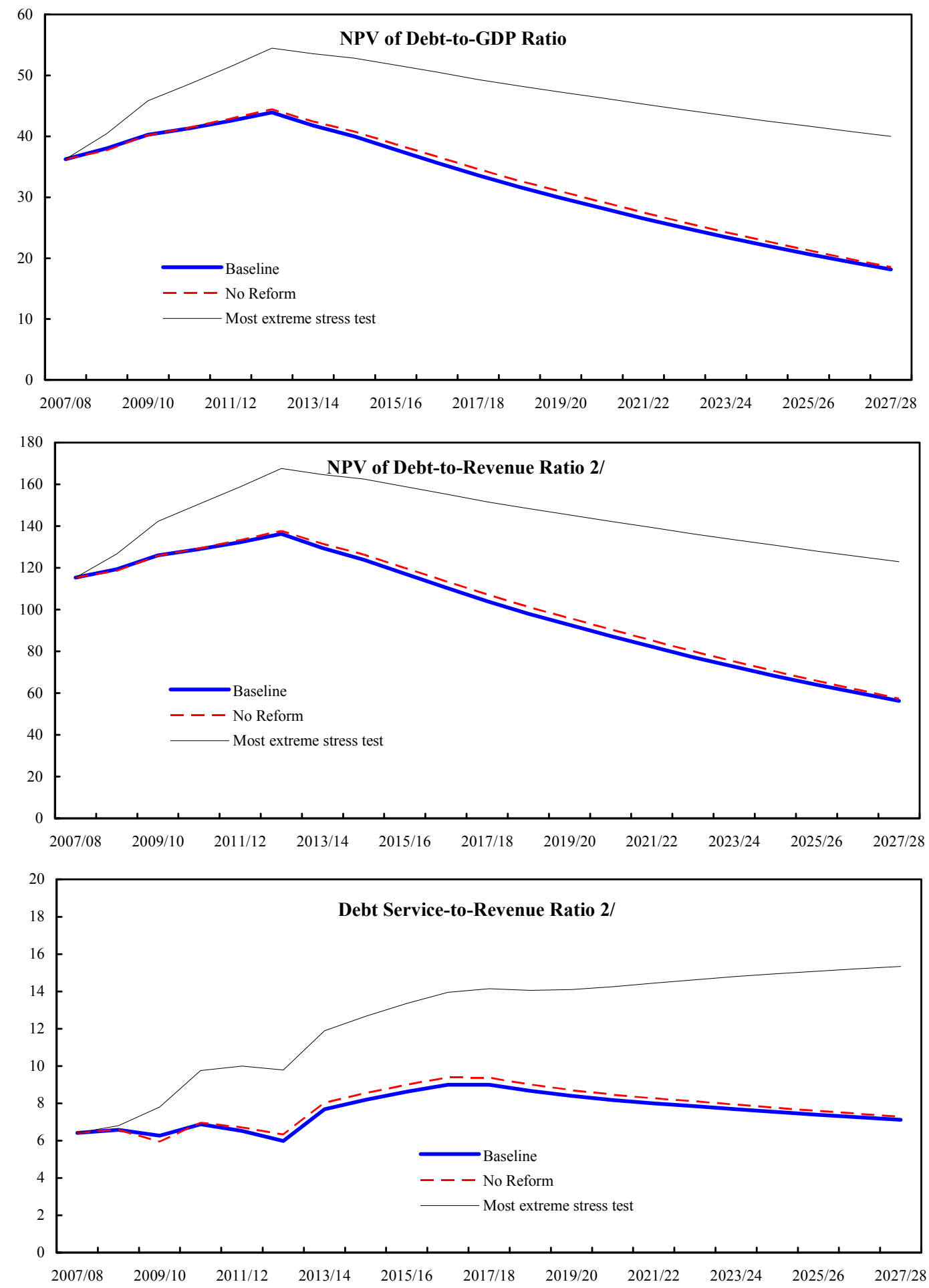

Sources: Staff projections and simulations.

$1 /$ Most extreme stress test is test that yields highest ratio in 2017/18.

$2 /$ Revenue including grants. 


\section{INTERNATIONAL MONETARY FUND}

\section{TONGA}

\section{Staff Report for the 2008 Article IV Consultation-Informational Annex}

\section{Prepared by the Staff Representatives for the 2008 Consultation with Tonga}

(In Consultation with Other Departments)

June 17, 2008

Contents

Page

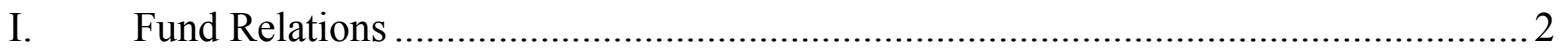

II. Relations with the Pacific Financial Technical Assistance Centre ........................... 3

III. Relations with the World Bank Group............................................................ 5

IV. Relations with the Asian Development Bank .................................................... 7

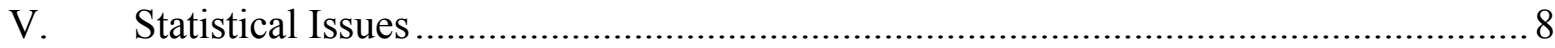


AnNex I. Tonga Fund Relations

(As of April 30, 2008)

I. Membership Status: Joined 9/13/85; Article VIII

II. General Resources Account:

Quota

Total holdings of currency

Reserve position in Fund

III. SDR Department:

Holdings
SDR Million

6.90

5.19

1.71

SDR Million

0.44
\% Quota

100.00

75.20

24.81

$\%$ Allocation

n.a.

IV. Outstanding Purchases and Loans: None.

V. Financial Arrangements: None.

VI. Projected Obligations to Fund: None.

VII. Exchange Rate Arrangement:

Since February 11, 1991, the value of the pa'anga is determined based on a weighted basket of currencies comprising the U.S., Australian, and New Zealand dollars, with the U.S. dollar as the intervention currency. In July 2000, the Japanese yen was added to the basket, and the monthly maximum adjustment limit was raised to 5 percent from 2 percent that had prevailed since March 1998, when the allowance for adjustment was introduced. Tonga has accepted the obligations of Article VIII, Sections 2, 3 and 4. Tonga presently imposes an exchange restriction subject to approval under Article VIII, Section 2(a). This restriction consists of the tax certification requirement imposed by the authorities on the making of payments and transfers for certain current international transactions: (i) payments for oil imports; (ii) airline ticket sales; (iii) payments for specified charges/fees/services;

(iv) insurance payments; (v) lease payments; (vi) payments for medical expenses incurred by residents; (vii) transfers by nonresidents of profits and dividends abroad; (viii) external loan payments; and (xi) maintenance payments including remittances for family living expenses.

VIII. Last Article IV Consultation:

Staff discussions were held during April 11-20, 2007 and the Executive Board discussed the staff report (IMF Country Report No. 07/297) on July 11, 2007.

IX. Technical Assistance:

LEG has provided assistance on AML/CFT issues for the Pacific islands countries, including Tonga, with an emphasis on risk management.

PFTAC has provided assistance on budgetary management; tax administration; banking legislation and supervision; and balance of payments and national accounts statistics.

X. Resident Representative: None. 


\section{AnNex II. TONGa: Relations With THE Pacific Financial Technical Assistance Centre ${ }^{1}$ (As of February 2008)}

Assistance to Tonga since 2002 included 31 advisory missions, mostly on tax and customs administration and banking. During 2000-06, Tonga has sent 54 officials to the Centre's regional seminars, workshops and training courses, and six attachments were organized.

\section{Public Financial Management}

Since 2003, PFTAC's missions have focused on complementing the considerable assistance provided by other TA agencies, including through the introduction of a midyear economic review and fiscal update, reconciliation of monetary and fiscal data, and changes in budget documentation. For the 2003/04 and 2004/05 budgets, assistance was provided in presenting the final aggregate budget figures on a GFSM2001 basis. In 2004, PFTAC arranged for a Tongan official to participate on a delegation of Pacific Island officials to the Australian Commonwealth Ministry of Finance. During 2005, the PFTAC PFM Advisor participated in a joint donor/government Feasibility Study related to a proposed long-term Financial and Economic Management Program (FEMP), as well as worked with the Ministry of Finance on assessing the financial implications of the proposed civil service wage increase. Since then assistance in the form of a peripatetic advisor has been provided in 2006, and again in 2007, to assist in revenue estimation work. The PFM Advisor has also delivered lectures on PFM to all CEOs, in late April 2007. A joint PFTAC mission on revenue estimation and Statistics is to visit Tonga in mid-March 2008 to further assist in these areas.

\section{Tax Administration and Policy}

A tax reform package, including a new consumption tax, was designed by PFTAC in 2002. Follow-up missions in 2003 and 2004 were designed to assist preparations for the implementation of that package. At the end of January 2005, the Minister of Finance announced a substantially altered plan to implement a consumption tax and some other changes on April 1, 2005. PFTAC was not requested to assist in its implementation. The Centre will, however, provide assistance in the redrafting of the Customs legislation. In late 2005, NZAID offered additional assistance to PFTAC to fund three short expert visits to Nuku'alofa to assist with revenue forecasting; the first of these missions took place in February 2006.

\footnotetext{
${ }^{1}$ The Pacific Financial Technical Assistance Centre (PFTAC) in Suva, Fiji is a regional technical assistance institution operated by the IMF with financial support of the Asian Development Bank, Australia, Japan, Korea and New Zealand. The Centre's aim is to build skills and institutional capacity for effective economic and financial management that can be sustained at the national level. Member countries are: Cook Islands, Federated States of Micronesia, Fiji, Kiribati, Marshall Islands, Nauru, Niue, Palau, Papua New Guinea, Samoa, Solomon Islands, Tokelau, Tonga, Tuvalu, and Vanuatu.
} 
Following the restructuring of the Public Service, PFTAC carried out a mission in September 2006. The mission also coincided with the public consultation of a new income tax and Customs bills, both based on self-assessment principles. The mission's primary recommendations related to the compliance management of large taxpayers, a post implementation review of the Consumption tax, workforce management-including change management and the managing of risk in the Customs. The mission identified a number of areas where PFTAC could be of further assistance. No formal response has been received to date which PFTAC recently followed up on. In that context, account does need to be taken of the disruption in Nuku'alofa of the recent civil riots and the resulting change to the governments priorities.

\section{Banking Sector Regulation and Supervision}

An assessment to determine compliance with the Basel Core Principles for Effective Banking Supervision (BCP) was conducted in 2002. It identified some shortcomings in Tonga's legal framework and resulted in a review of the Financial Institutions Act (FIA). The enhanced FIA was enacted in late 2004. A TA mission provided assistance with drafting regulations and guidelines, and establishing procedures for their implementation in April 2005. Further assistance in supervision was provided in late 2005 and again in February 2006, as the on-site examination process has been regularized with PFTAC assistance. Amendments to the NRBT Act, which will strengthen the central bank's enforcement capacity, are still awaiting Parliament's enactment. PFTAC also arranged, through funding provided in late 2005 by NZAID, for the renewal of the secondment of a central banking manager from the Reserve Bank of Fiji to serve as the Deputy Governor of the National Reserve Bank of Tonga.

\section{Economic and Financial Statistics}

In 2002, two reviews were undertaken in accordance with the GDDS and the Data Quality Assessment Framework; one on BOP statistics and the other on the wider statistical system. Subsequent missions in 2004 finalized GDDS metadata, provided training in BOP concepts and practices, developed a new BOP business survey, and reviewed national accounts data. In September 2005 a partial update of the 2002 statistical system review was done, focused on outputs of the Statistics Division of the Ministry of Finance. Further assistance was provided to peer review GDP and BOP estimates prior to publication. GDDS metadata was approved and published in 2006 on the Data Dissemination Bulletin Board. A TA mission in April 2007 provided further assistance with reviewing BOP statistics. In addition to the joint PFTAC mission on revenue estimation and statistics in mid-March 2008, a further TA mission is planned for early June 2008 to assist the Statistics Division with GDP and BOP estimates. 


\section{AnNeX III. Tonga: Relations With THE WORLd BANK GrouP ${ }^{2}$}

(As of May 2008)

Since becoming a World Bank Group member in 1985, Tonga has received a total of five IDA credits totaling SDR 15.2million (original amount USD equivalent of 22.8 million). Tonga is eligible for an IDA 14 allocation of SDR 4.2 million (indicative only) over FY2006-08. The key components of the Bank's current program in Tonga are:

- Health: The Tonga Health Sector Support Project (USD10.9 million credit approved in mid2003) aims to support the Government in improving the performance of its health sector through appropriate health financing policy, revised health information systems, and improved management and infrastructure of the country's main hospital. Construction of the hospital, which is the major component of the project, has been satisfactorily completed. Health financing policy has been developed and mechanisms of implementation are being finalized.

- Natural Hazard Management: The Cyclone Emergency Recovery and Management Project, with an IDA credit of US\$5.9 million approved in 2002, is assisting Tonga in replacing and strengthening the resilience of social infrastructure and helping upgrade Tonga's emergency and risk management capacity to ensure it can cope better with future disasters and the risk posed by climate change.

- Education System: The Tongan Education Support Project with an IDA credit of US\$1.0 million and an NZAID trust fund of US\$4.1 million (managed by the Bank) was approved in June 2005. The project's school grants fund (1) has been successfully implemented in its first phase with nearly all schools having received grants on a capitation basis and spent over $80 \%$ of the funds on educational materials and maintenance, and (2) has been successfully evaluated, and lessons learned will be addressed in the second phase. At the request of the Government of Tonga, the IDA Credit Agreement was amended in January 2008 to allocate IDA funding to the third phase of the school grants program in 2009 .

- Financial Management and Procurement: An IDF grant of US\$200,000 was approved in December 2003 to support public procurement reforms and procurement capacity building through the provision of technical assistance. The draft Procurement Law, prepared by the government-appointed consultant and based on the UNCITRAL Model Law, has been reviewed by the Bank and comments were provided to the Government. It is being revised by the Ministry of Finance (MoF) and Crown Law. Implementation for activities 2 and 3 (manual, standard bidding documents and training) is under way as MOF has just appointed an individual consultant to provide assistance in the area.

\footnotetext{
${ }^{2}$ Prepared by World Bank staff.
} 
- Transport Sector Reform: The Bank has completed a Transport Sector Review Study that provides analytical assistance to support the Government's commitment to improve the structure and efficiency of the sector, including assessing options for sustainable financing. A study of opportunities for public-private partnership in the airport sector was completed in April 2006, leading to the corporatization of the airport on a business basis. The Bank is preparing a lending program to help the Ministry of Transport to consolidate its recent laws and realign its functions, as well as to improve inter-island ferry services (the project is scheduled to go to the board on June 26, 2008). There is a tentative follow up Tonga Transport project for FY11 which will draw upon the findings of a planned study on infrastructure needs (supported by the new Pacific Regional Infrastructure Facility).

- Private Sector Development: The World Bank Group has an active BEE program through the trilaterally funded (IFC, FIAS, World Bank) Tonga Implementation of Regulatory Reform Program (US\$700,000 over two years). A draft MoU for a new BEE project is currently with the Ministry of Finance for review. This project will build upon work carried out under the previous Tonga Regulatory Reform Phase II. Under that project a Taskforce for the Implementation of Regulatory Reform was established in January 2006, overseeing four public-private Working Groups: Starting a Business; Licenses and Permits; Fishing (tax focus); and Immigration. The membership of the Taskforce comprises four Ministers and four senior private sector representatives, and its mandate is to identify and remove regulatory impediments to private sector growth.

\section{Recent Reports/Policy Notes:}

- $\quad$ East Asia and Pacific Update: Testing Times Ahead, April 2008

- At Home and Away-Expanding Job Opportunities for Pacific Islanders through Labor Mobility, August 2006

- Opportunities to Improve Social Services: Human Development in the Pacific Islands, 2006

- The Pacific Infrastructure Challenge, 2006

- Not If, But When: Adapting to Natural Hazards in the Pacific Islands Region, 2006

- Pacific Regional Strategy FY2006-2009, May 2005

\section{World Bank Credits (in millions of U.S. dollar equivalent, as of May 16, 2008)}

$\begin{array}{ll}\text { Total disbursed } & 22.1 \\ \text { Undisbursed } & 5.84\end{array}$




\section{Annex IV. Tonga: Relations With the Asian DeVelopment Bank ${ }^{3}$}

(As of February 2008)

The Asian Development Bank (AsDB) strategy for Tonga supports the Government's Strategic Development Plan Eight 2006/07-2008/09 (SDP-8) development goals aimed at creating a society in which all Tongans enjoy higher living standards and a better quality of life. The government's strategic objectives emphasize the need to have an average budget deficit less than 2 percent of GDP, inflation below 7 percent, GDP growth in the 3-4 percent range and a reduction in the poverty headcount index below 23 percent, through a dynamic and highly competitive economy driven mainly by the private sector and an efficient public sector.

As agreed with the government, the new Country Partnership Strategy (CPS) 2007-2012 for Tonga will support the SDP-8 implementation in alignment with the objectives of the 2005 Paris Declaration on Aid Effectiveness. The CPS will focus on poverty reduction by means of three intervention pillars - pro-poor, environmentally sustainable integrated urban infrastructure development; financing of pro-poor policies through effective, prudent macroeconomic and fiscal management; and private sector development - that address binding constraints on growth. Capacity strengthening and institution building will be among the key outcomes of the results-based CPS. The CPS outcomes expected are (i) improved fiscal governance, (ii) improved social services delivery in urban areas, and (iii) an improved private sector-enabling environment.

AsDB has approved 15 loans totaling \$57.8 million from the Asian Development Fund (ADF) to Tonga since it joined AsDB in 1972. Fifty-four technical assistance projects with a value of $\$ 15.3$ million were also provided to improve capacity and strengthen institutional development in various sectors. Past AsDB investments have focused on finance development and infrastructure development in transport, power, agriculture, and fisheries.

Active projects include five TAs in the country portfolio. The latest loan on Economic and Public Sector Reform was completed successfully in 2004. The five ongoing TAs focus on public enterprise reforms, youth micro-enterprise development, preparing the integrated urban development projects, support for the implementation of SDP-8, and Rationalization of Public Enterprises, Phase III. Another TA on strengthening pro-poor policy in the Pacific for Tonga for $\$ 0.2 \mathrm{~m}$ has been implemented on a regional basis to support economic sector work and some work is being prepared to complete that work. It is counted as country TA.

Tonga: Loan and Technical Assistance Approvals, 2002-06

\begin{tabular}{lccccc}
\hline & 2002 & 2003 & 2004 & 2005 & 2006 \\
\hline $\begin{array}{l}\text { Loan approvals } \\
\text { Number }\end{array}$ & 1 & 0 & 0 & 0 & 0 \\
$\quad$ Amount (in millions of U.S. dollars) & 10 & 0 & 0 & 0 & 0 \\
$\quad$ Technical assistance approvals & & & & & 2 \\
$\quad$ Number & 1 & 3 & 3 & 1 & 0.9 \\
$\quad$ Amount (in millions of U.S. dollars) & 0.7 & 0.9 & 0.7 & 0.7 & \\
\end{tabular}

\footnotetext{
${ }^{3}$ Prepared by Asian Development Bank staff.
} 


\section{AnNeX V. TONGa: StATistical IsSUES}

While economic statistics are broadly adequate for surveillance, data deficiencies continue to complicate the monitoring of economic conditions and policy formulation. The Statistics Department (SD) and the Ministry of Finance (MOF) have received, on a regular basis, technical assistance in national accounts, government finance, and balance of payments (BOP) statistics from STA as well as the Pacific Financial Technical Assistance Centre (PFTAC); nevertheless, data provision to the Fund continues with long delays.

The two main sources of statistical information are the Quarterly Bulletin of the National Reserve Bank of Tonga (NRBT), and the annual and semi-annual budget reports from the MOF. The country has been participating in the GDDS since May 30, 2006. The metadata are posted on the Fund's Dissemination Standards Bulletin Board (http://dsbb.imf.org/Applications/web/gdds/gddscountrycategorylist/?strcode=TON ).

\section{Real Sector Statistics}

The national account estimates are based primarily on the production approach; only rough estimates of expenditure components are available. The SD has completed the revision of the national accounts (base period 2000/01), based on the results of a new business establishment survey, and with technical assistance from the Secretariat for the Pacific Community. However, the response rates are very poor and there are major delays in data processing due to staff capacity and shortages. In August 2004, a PFTAC mission proposed improvements to source data and methodologies and suggested revisions of recent GDP estimates. A follow up mission took place in March 2008 with a focus on balance of payments and national accounts estimates and building linkages between government finance and national accounts statistics. The mission found only a few of the GDP components were compiled to a reasonable standard and were based on actual data (e.g. electricity and water supply). The mission raised concerns about the widespread use in compilation of out-of-date fixed ratios, extrapolations not founded on good data, and inappropriate price deflators.

The Consumer Price Index is based on a basket of goods and services from the 2000/01 Household Income and Expenditure Survey. Technical assistance is being provided in 2008 on the development of an import price index.

Labor market statistics are weak: employment statistics have not been compiled since 2003; and average earnings statistics are not available.

\section{Government Finance Statistics}

The FY 2002/03 Budget Statement introduced a presentation of fiscal data compiled according to the methodology of the 2001 Government Finance Statistics Manual. However, improvements are still needed to ensure accurate and reliable fiscal data. Proper classification of transactions is needed to permit reconciliation with monetary financing data. Lags in updating the accounting system should be shortened. Published data are often subject to significant revisions. No data are reported for publication in the IFS or GFS Yearbook. 


\section{External Sector Statistics}

Official BOP statistics are compiled annually by the SD with long lags. Monthly trade figures, derived from customs data, are available with a three-month lag. Unofficially, the NRBT compiles monthly balance of payments statistics based on the Overseas Exchange Transactions records of the banking system with a six-week lag. There are significant differences between the BOP estimates compiled by the two agencies. Moreover, large errors and omissions point to possible under recording of imports. Work is needed to reconcile the data on stocks of reserve assets that are available from various data sources. The MOF has put in place a system that provides detailed information on official sector external disbursements and debt service.

\section{Monetary and Financial Statistics}

Until recently, the reporting of monetary and financial statistics (MFS) to the Fund for publication in International Financial Statistics (IFS) was irregular. This was particularly worrisome since these data are shared with APD through an integrated monetary database. This situation has improved, as the NRBT now reports data for the central bank, other depository corporations, and monetary aggregates using the standardized report forms (SRFs). These data were published for the first time in the March 2008 issue of IFS and IFS Supplement on Monetary and Financial Statistics. The NRBT will have to allocate resources to improve the quality of MFS by obtaining source data suitable for compilation of the SRFs in line with the recommendations of the Monetary and Financial Statistics Manual. 
Tonga: Table of Common Indicators Required for Surveillance

(As of May 18, 2008)

\begin{tabular}{|c|c|c|c|c|c|}
\hline & $\begin{array}{c}\text { Date of } \\
\text { latest } \\
\text { observation }\end{array}$ & $\begin{array}{l}\text { Date } \\
\text { received }\end{array}$ & $\begin{array}{c}\text { Frequency } \\
\text { of } \\
\text { Data }^{6}\end{array}$ & $\begin{array}{l}\text { Frequency } \\
\text { of } \\
\text { Reporting }^{6}\end{array}$ & $\begin{array}{c}\text { Frequency } \\
\text { of } \\
\text { publication }\end{array}$ \\
\hline Exchange Rates & $3 / 2008$ & $5 / 2008$ & M & M & $M$ \\
\hline $\begin{array}{l}\text { International Reserve Assets and Reserve Liabilities of } \\
\text { the Monetary Authorities } 1\end{array}$ & $1 / 2008$ & $2 / 2008$ & M & M & $M$ \\
\hline Reserve/Base Money & $3 / 2008$ & $5 / 2008$ & M & M & $M$ \\
\hline Broad Money & $3 / 2008$ & $5 / 2008$ & M & M & $M$ \\
\hline Central Bank Balance Sheet & $3 / 2008$ & $5 / 2008$ & M & M & $M$ \\
\hline Consolidated Balance Sheet of the Banking System & $3 / 2008$ & $5 / 2008$ & M & M & $M$ \\
\hline Interest Rates $^{2}$ & $3 / 2008$ & $5 / 2008$ & M & M & $M$ \\
\hline Consumer Price Index & $11 / 2007$ & $2 / 2008$ & M & M & $M$ \\
\hline $\begin{array}{l}\text { Revenue, Expenditure, Balance and Composition of } \\
\text { Financing }{ }^{3}-\text { General Government }\end{array}$ & NA & NA & NA & NA & $N A$ \\
\hline $\begin{array}{l}\text { Revenue, Expenditure, Balance and Composition of } \\
\text { Financing }{ }^{3} \text { - Central Government }\end{array}$ & $12 / 2007$ & $1 / 2008$ & M & Q & $Q$ \\
\hline $\begin{array}{l}\text { Stocks of Central Government and Central Government- } \\
\text { Guaranteed Debt }{ }^{5}\end{array}$ & $6 / 2007$ & $1 / 2008$ & A & A & $A$ \\
\hline External Current Account Balance & Q3/2007 & $1 / 2008$ & Q & Q & $Q$ \\
\hline Exports and Imports of Goods and Services & Q3/2007 & $1 / 2008$ & Q & Q & $Q$ \\
\hline GDP/GNP & 2007 & $1 / 2008$ & A & A & $A$ \\
\hline Gross External Debt & $6 / 2007$ & $1 / 2008$ & $A$ & $A$ & $A$ \\
\hline
\end{tabular}

${ }^{1}$ Includes reserve assets pledged or otherwise encumbered as well as net derivative positions.

${ }^{2}$ Both market-based and officially-determined, including discount rates, money market rates, rates on treasury bills, notes and bonds.

${ }^{3}$ Foreign, domestic bank, and domestic nonbank financing.

${ }^{4}$ The general government consists of the central government (budgetary funds, extra budgetary funds, and social security funds) and state and local governments.

${ }^{5}$ Including currency and maturity composition.

${ }^{6}$ Daily (D), Weekly (W), Monthly (M), Quarterly (Q), Annually (A), Irregular (I); Not Available (NA). 


\section{IMF Executive Board Concludes 2008 Article IV Consultation with Tonga}

On July 2, 2008, the Executive Board of the International Monetary Fund (IMF) concluded the Article IV consultation with Tonga. ${ }^{1}$

\section{Background}

Tonga's economy has shown resilience in the aftermath of the November 2006 riots and is now on a path to recovery. The key factor underpinning this resilience has been private investment. Donor-supported government reconstruction loans are expected to add further momentum to the recovery. However, the global upswing in fuel and food prices has intensified pressure on inflation and external reserves, the latter mitigated to a large extent by strong inflows of remittances.

Real GDP contracted by about 31/4 percent in FY06/07 (ending June), following the November 2006 riots, but the private sector quickly relocated businesses and replenished lost inventories. Preliminary indicators for the first half of FY07/08 suggest that the economy is on a path to recovery led by the services sector.

Adverse terms of trade shocks contributed to inflation pressures. Major increases in external food and fuel prices, combined with a nominal depreciation of the pa'anga against the currencies of major trading partners, have led to a marked increase in CPI inflation, which reached 121/2 percent at end-March 2008 (from 63/4 percent at end- December 2007).

\footnotetext{
${ }^{1}$ Under Article IV of the IMF's Articles of Agreement, the IMF holds bilateral discussions with members, usually every year. A staff team visits the country, collects economic and financial information, and discusses with officials the country's economic developments and policies. On return to headquarters, the staff prepares a report, which forms the basis for discussion by the Executive Board. At the conclusion of the discussion, the Managing Director, as Chairman of the Board, summarizes the views of Executive Directors, and this summary is transmitted to the country's authorities.
} 
Tonga's external position is expected to weaken, reflecting mainly the impact of rising food and fuel prices. The current account deficit is projected to remain high in FY07/08 at about 10 percent of GDP, as sharp increases in imports, reflecting the economy's heavy reliance on oil imports, are matched by increases in remittances. External reserves have declined somewhat since last June, but are expected to stabilize at around 3-months of imports at endFY07/08 on account of the projected improvements in official and private capital inflows.

Significant efforts have been made to achieve a balanced budget in FY07/08. During the first nine months of $\mathrm{FY} 07 / 08$, revenue performance remained buoyant, boosted by a recovery of arrears and a containment of the public wage bill and nonwage spending. The authorities have proposed a balanced budget in FY08/09 to limit domestic and nonconcessional external borrowing. The budget proposes over 20 percent growth in tax revenue to support higher maintenance and capital spending. At the same time, the budget also propose a reduction of maximum tariff rates and increase in the individual income tax exemption threshold, together with a reduction in the corporate tax rate for large taxpayers.

Monetary policy was eased in several steps in early 2007 to support economic recovery. At the time, inflation was less of a concern. The impact of monetary easing has only started to materialize recently. Private sector credit growth picked up gradually. It reached $161 / 2$ percent $(\mathrm{y} / \mathrm{y})$ at end-February 2008, from 61/2 percent at end-March 2007. Banks' business loans, however, grew at a faster pace (to almost 30 percent by end-December 2007), while growth in housing loans has been relatively slow.

Tonga's total public debt stock declined to $451 / 4$ percent of GDP in FY06/07 from 481/2 percent of GDP in FY05/06. External debt to GDP fell as donor financing declined in real terms, while fiscal consolidation to limit domestic budget financing also contributed to a downward trend in domestic public debt to GDP. Following the civil unrest in November of 2006, the government made a significant effort toward securing financing for the reconstruction of the capital city of Nuku'alofa; the government contracted a long-term soft loan of about US\$63 million (or 23 percent of GDP in FY07/08), but disbursements of this loan have been postponed.

\section{Executive Board Assessment}

Executive Directors welcomed the resilience of the Tongan economy in the aftermath of the November 2006 riots. With political stability now restored, private investment is picking up and near-term growth prospects have become more favorable, especially in the tourism and construction sectors. Directors considered that attention should now turn to rebalancing the economic policy mix, in order to address the inflationary risks and external vulnerabilities arising from increases in world food and fuel prices.

Directors commended the authorities for the progress they have made in ensuring fiscal prudence, including the recovery of tax arrears and the containment of the public wage bill and nonwage spending. They welcomed the planned balanced budget in FY07/08, which is evidence of strengthened fiscal discipline, and considered it to be essential to maintain a 
tightened fiscal stance in FY08/09 in order to help fight inflation. Directors called for a more orderly public sector wage policy to reduce fiscal vulnerability.

Directors recommended an early monetary tightening to support fiscal policy in the effort to contain inflation and anchor inflation expectations. This should be achieved through the increased use of market-based instruments, including the issuance of reserve bank notes. Directors encouraged the authorities to step up prudential measures to help monitor the fast growth in business loans.

Directors agreed that Tonga's current balance of payments position appears broadly sustainable, and considered that external price competitiveness has been generally preserved. However, in light of the sustained rise in international fuel and food prices, they recommended monitoring trade performance closely. Directors took note of the staff assessment that the real effective exchange rate of the Tongan pa'anga is close to its equilibrium level. At the same time, they observed that allowing some greater exchange rate flexibility, underpinned by appropriately tight fiscal and monetary policies, would help ensure external stability and safeguard external reserves, although it was recognized that the potential inflationary impact of such a move would need to be monitored carefully.

Directors stressed the importance of assessing the debt sustainability implications of the reconstruction loan contracted with a major donor. They cautioned that the loan, as currently structured, could increase Tonga's risk of debt distress, although the large remittance inflows could help mitigate this risk. Directors therefore welcomed the authorities' decision to review the size of the loan to ensure that it is consistent with Tonga's medium-term fiscal framework, its implementation capacity, and real sector business needs, and to best utilize this loan over a suitable longer time horizon. They called on the authorities to strengthen their public debt management policy and limit the recourse to non-concessional borrowing to ensure debt sustainability over the medium term.

Directors commended the authorities for the progress made in the corporatization and privatization of public enterprises, as well as the measures to improve governance. The Procurement Bill has been implemented, which will make government contracting more transparent, and a task force has been set up to review administrative impediments to business. Directors recommended revisiting plans for the government to purchase the electricity company, bearing in mind the financial burden and the quasi-fiscal and governance risks of such a step. A better alternative would be to seek private investors to acquire the company.

Directors encouraged the authorities to work closely with technical assistance providers to improve further Tonga's statistical capacity, particularly in the areas of national accounts and price statistics. 
Public Information Notices (PINs) form part of the IMF's efforts to promote transparency of the IMF's views and analysis of economic developments and policies. With the consent of the country (or countries) concerned, PINs are issued after Executive Board discussions of Article IV consultations with member countries, of its surveillance of developments at the regional level, of post-program monitoring, and of ex post assessments of member countries with longer-term program engagements. PINs are also issued after Executive Board discussions of general policy matters, unless otherwise decided by the Executive Board in a particular case. The staff report (use the free Adobe Acrobat Reader to view this pdf file) for the 2008 Article IV Consultation with Tonga is also available. 
Tonga: Selected Economic Indicators, 2003/04-2008/09 1/

\begin{tabular}{|c|c|c|c|c|c|c|}
\hline & $2003 / 04$ & $2004 / 05$ & $\begin{array}{r}\text { Prel. } \\
2005 / 06 \\
\end{array}$ & $\begin{array}{r}\text { Prel. } \\
2006 / 07 \\
\end{array}$ & $\begin{array}{r}\text { Proj. } \\
2007 / 08 \\
\end{array}$ & $\begin{array}{r}\text { Proj. } \\
2008 / 09 \\
\end{array}$ \\
\hline \multicolumn{7}{|l|}{ Output and prices (in percent change) } \\
\hline Real GDP & 1.0 & -0.4 & 0.6 & -3.2 & 1.2 & 2.6 \\
\hline Consumer prices (period average) & 11.7 & 9.7 & 7.0 & 5.1 & 14.5 & 12.3 \\
\hline \multicolumn{7}{|l|}{ Central government finance (in percent of GDP) } \\
\hline Total revenue and grants & 29.9 & 28.7 & 33.4 & 33.2 & 31.4 & 31.8 \\
\hline Total expenditure and net lending & 29.5 & 26.3 & 34.9 & 34.3 & 31.4 & 32.1 \\
\hline Overall balance (incl. reconstruction loan) & 0.3 & 2.5 & -1.5 & -1.0 & 0.0 & -0.3 \\
\hline Overall balance (excl. reconstruction loan) & 0.3 & 2.5 & -1.5 & -1.0 & 0.0 & -0.3 \\
\hline External financing (net) & 3.4 & 0.3 & 0.5 & 0.2 & 0.3 & -0.2 \\
\hline Domestic financing (net) & -3.8 & -2.8 & 1.0 & 0.9 & -0.6 & 0.0 \\
\hline \multicolumn{7}{|l|}{ Money and credit (in percent change) } \\
\hline Total liquidity $2 /$ & 16.7 & 13.3 & 13.3 & 13.3 & 13.7 & $\ldots$ \\
\hline Of which: Broad money (M2) & 18.9 & 12.8 & 16.6 & 11.9 & 14.7 & $\ldots$ \\
\hline Domestic credit & -10.9 & 20.9 & 25.8 & 11.6 & 15.1 & $\ldots$ \\
\hline Private sector credit & -4.3 & 29.4 & 22.6 & 9.5 & 15.5 & $\ldots$ \\
\hline \multicolumn{7}{|l|}{ Balance of payments (in millions of U.S. dollars) } \\
\hline Exports, f.o.b. & 13.8 & 16.0 & 15.4 & 13.3 & 14.8 & 15.5 \\
\hline Imports, f.o.b. & -82.6 & -105.4 & -122.2 & -108.6 & -135.0 & -154.3 \\
\hline Services (net) & -2.8 & -10.0 & -7.8 & -17.9 & -14.4 & -13.6 \\
\hline Income (net) & -0.4 & 1.6 & 2.8 & 3.5 & 3.7 & 3.6 \\
\hline Services and income (net) & -3.2 & -8.4 & -5.0 & -14.4 & -10.7 & -10.0 \\
\hline Transfers (net) & 79.7 & 91.9 & 88.9 & 84.2 & 104.1 & 126.0 \\
\hline Current account balance (excl. reconstruction loan) & 7.7 & -5.8 & -22.8 & -25.5 & -26.8 & -22.8 \\
\hline Current account balance (incl. reconstruction loan) & 7.7 & -5.8 & -22.8 & -25.5 & -26.8 & -22.8 \\
\hline (In percent of GDP) & 4.2 & -2.6 & -9.7 & -10.4 & -10.4 & -8.8 \\
\hline \multicolumn{7}{|l|}{ Gross international reserves } \\
\hline In millions of U.S. dollars & 44.8 & 42.5 & 40.4 & 47.1 & 43.4 & 46.0 \\
\hline In months of total imports & 4.8 & 3.7 & 3.1 & 3.9 & 3.0 & 2.8 \\
\hline \multicolumn{7}{|l|}{ External debt (in percent) } \\
\hline External debt (in percent of GDP) & 42.9 & 36.1 & 35.4 & 33.2 & 29.8 & 31.4 \\
\hline Debt service ratio $3 /$ & 8.2 & 8.0 & 7.5 & 9.8 & 11.0 & 10.5 \\
\hline \multicolumn{7}{|l|}{ Exchange rate (period average) } \\
\hline Pa'anga per U.S. dollar & 2.0 & 1.9 & 2.0 & 2.0 & 1.9 & $\ldots$ \\
\hline Real effective exchange rate $(1990=100) 4 /$ & 93.8 & 100.2 & 103.6 & 103.4 & 104.1 & $\ldots$ \\
\hline Nominal effective exchange rate $(1990=100) 4 /$ & 71.4 & 71.1 & 70.5 & 68.4 & 66.0 & $\ldots$ \\
\hline
\end{tabular}

Sources: The Tongan authorities; IMF staff estimates and projections.

1/ Fiscal year beginning July.

2/ From the Banking Survey, which includes the Tonga Development Bank.

$3 /$ In percent of exports of goods and services.

4/ Through end-December 2006. 